\title{
Molecular Targets for PET Imaging of Activated Microglia: The Current Situation and Future Expectations
}

\author{
Claire Tronel ${ }^{1, *}$, Bérenger Largeau ${ }^{2}$, Maria Joao Santiago Ribeiro ${ }^{1,2}$, Denis Guilloteau ${ }^{1,2}$, \\ Anne-Claire Dupont ${ }^{1,2}$ and Nicolas Arlicot ${ }^{1,2}$ \\ 1 INSERM U930, Université François Rabelais de Tours, 10 boulevard Tonnelé, 37032 Tours, France; \\ maria.ribeiro@univ-tours.fr (M.J.S.R.); denis.guilloteau@univ-tours.fr (D.G.); \\ ac.dupont@chu-tours.fr (A.-C.D.); nicolas.arlicot@univ-tours.fr (N.A.) \\ 2 CHRU de Tours, 37044 Tours, France; berenger.largeau@etu.univ-tours.fr \\ * Correspondence: claire.tronel@univ-tours.fr; Tel.: +33-(0)2-4736-6346
}

Academic Editors: Styliani-Anna E. Tsirka and Jillian Nissen

Received: 31 January 2017; Accepted: 28 March 2017; Published: 11 April 2017

\begin{abstract}
Microglia, as cellular mediators of neuroinflammation, are implicated in the pathogenesis of a wide range of neurodegenerative diseases. Positron emission tomography (PET) imaging of microglia has matured over the last 20 years, through the development of radiopharmaceuticals targeting several molecular biomarkers of microglial activation and, among these, mainly the translocator protein-18 kDa (TSPO). Nevertheless, current limitations of TSPO as a PET microglial biomarker exist, such as low brain density, even in a neurodegenerative setting, expression by other cells than the microglia (astrocytes, peripheral macrophages in the case of blood brain barrier breakdown), genetic polymorphism, inducing a variation for most of TSPO PET radiopharmaceuticals' binding affinity, or similar expression in activated microglia regardless of its polarization (pro- or anti-inflammatory state), and these limitations narrow its potential interest. We overview alternative molecular targets, for which dedicated radiopharmaceuticals have been proposed, including receptors (purinergic receptors P2X7, cannabinoid receptors, $\alpha 7$ and $\alpha 4 \beta 2$ nicotinic acetylcholine receptors, adenosine $2 \mathrm{~A}$ receptor, folate receptor $\beta$ ) and enzymes (cyclooxygenase, nitric oxide synthase, matrix metalloproteinase, $\beta$-glucuronidase, and enzymes of the kynurenine pathway), with a particular focus on their respective contribution for the understanding of microglial involvement in neurodegenerative diseases. We discuss opportunities for these potential molecular targets for PET imaging regarding their selectivity for microglia expression and polarization, in relation to the mechanisms by which microglia actively participate in both toxic and neuroprotective actions in brain diseases, and then take into account current clinicians' expectations.
\end{abstract}

Keywords: microglial activation; neuroinflammation; PET; biomarker; neurodegenerative disorders

\section{Microglia: From Resting to Activated Phenotypes}

Microglia cells were first identified by Nissl in 1899, who already suggested that they can exert phagocytosis and migration [1]. Pio del Rio-Hortega, in 1921, defined them as cells with ramifications, able to transform after a pathologic event and to acquire ameboid morphology, as well as to migrate, proliferate, and exert phagocytosis [2]. Microglial cells are resident immune cells of the brain and the most important effector of brain innate immunity. Their capacities (motility, proliferation, phagocytosis, secretion of soluble molecules, etc.) are very close to those of macrophages, and microglial cells are often called "brain macrophages". Nevertheless, after 50 years of debate, it is now commonly recognized that microglia and macrophages have different genesis. Macrophages are produced in the bone marrow 
from the post-natal stage, whereas microglia are derived from yolk sac progenitors migrating in the neuroepithelium at the early stage of embryonic life [3,4]. Despite this difference, these two types of cells require the same proliferation and differentiation factors and share identical receptors $(C D 11 b$, CD14, etc.).

Microglial cells represent between $5 \%$ and $10 \%$ of adult brain cells. They are present in all brain areas, but with variable density, even in physiological conditions, up to 10-fold in the human brain [5]. Anatomically, microglia cells are more expressed in the telencephalon or diencephalon than mesencephalon [6]. Their repartition varies also between gray and white matter and according to axons' myelination, since myelinated parts of the brain have a higher density of microglial cells than non-myelinated areas in the same brain region [7]. A recent study in rhesus macaques points out that microglial cell density, especially in gray matter, is modified during the life-span and increases with aging [8]. Furthermore, as reported by Pintado and colleagues [9], in rats, following brain lipopolysaccharide (LPS) injection, differences in microglia brain distribution, density, and functionality were associated with different sites of injection. More recently, a genome-wide study on mice showed that microglia from several brain regions and at different ages presented differences of gene expression [10].

Kreutzberg [11] was the first to characterize microglia morphological changes occurring during microglia activation. In mature and healthy central nervous systems (CNS), microglia present a ramified morphology, with a small soma and thin cellular processes. This state corresponds to "quiescent" or "resting" microglia. Resting microglia express few surface markers and have been considered for years as functionally inactive. Nonetheless, in vivo study on microglia-GFP (green fluorescent protein) transgenic mice showed that these ramifications have a high motility allowing microglial cells to survey their environment in an active way [12]. Microglial cells are sensors of brain integrity, since any change of brain homeostasis will induce their activation through a modification of gene expression, morphology, and function $[13,14]$. Activated microglia show several morphological changes. First, the cell ramification number is increased and these ramifications are thicker, so that cells acquire an amoeboid phenotype, very close to peripheral macrophages [15].

For years, microglia activation was supposed to be a "yes or no" phenomenon, with cells only known to be resting or activated. In the last ten years, it has become clear that microglia activation processes are much more complex. As well as peripheral macrophages, microglial cell activation is a sequential process, leading to distinct phenotypes and functions of these cells depending on the stimulus leading to their activation $[16,17]$. The classification and characterization of the different subpopulation of microglial cells is based on these definitions for peripheral macrophages [18]. Classically or pro-inflammatory (M1) activated microglia are activated by LPS and interferon $\gamma$ (IFN $\gamma$ ). M1 microglial cells secrete reactive oxygen species (ROS), as well as pro-inflammatory cytokines, such as interleukin (IL)-1 $\beta$ and tumor necrosis factor (TNF)- $\alpha$. Their activation may lead to tissue inflammation $[19,20]$. Alternative or anti-inflammatory microglial cells (M2) are divided into three subpopulations. M2a cells are activated by IL-4 or IL-13 and produce growth factors (insulin growth factor (IGF)-1) and anti-inflammatory cytokines (IL-10). They participate in tissue reparation, and also have an important phagocytosis capacity, involving them in the cleaning of cellular debris [21,22]. $\mathrm{M} 2 \mathrm{~b}$ cells are induced by immune complexes, secrete IL-10, and regulate the immune response [23]. Finally, IL-10, or glucocorticoids, will lead to the M2c phenotype, also called "acquired deactivation", producing tumor growth factor-(TGF) $\beta$ [24]. As brain immune cells, the principal function of microglia is to protect the brain against injury. They are the first actors in brain inflammation, even if other cells, mostly astrocytes, are also involved.

\section{Involvement of Activated Microglia in Brain Disorders}

Microglia activation is basically a beneficial phenomenon in response to neuron injury. Microglial cells phagocytose apoptotic neurons and secrete inflammatory factors to attract other immune cells to the site of injury. Inflammation resolution is well regulated and occurs when injury has been 
treated [25]. Nevertheless, it is now clearly established that neuroinflammation takes part in the process of most brain diseases, either in acute (traumatic brain injury (TBI), stroke) or in chronic, neurodegenerative diseases. Glutamate, adenosine triphosphate (ATP), chemokines, or superoxide are released by apoptotic brain cells (neurons, astrocytes) and lead to microglia activation through specific receptors.

In stroke or TBI, microglia activation appears in the hours following injury, release pro-inflammatory factors and chemoattractant molecules recruiting peripheral immune cells (macrophages and lymphocytes), and participate to neuronal death. Moreover, chronic neuronal death takes place in the weeks or months after these injuries and is strongly associated with microglia activation [26,27]. Molecules with anti-inflammatory effects have shown neuroprotection in preclinical models of stroke [28] and TBI [29]. These preclinical results lead to clinical study using anti-inflammatory molecules on stroke patients. Results of these clinical trials are variable and reviewed in Veltkamp and Gill [30].

In neurodegenerative diseases, the first involvement of neuroinflammation was described in Alzheimer's disease (AD) patients for whom activated microglial cells were detected in post-mortem nearby senile plaques [26]. Later, epidemiological studies suggest that long-term daily consumption of non-steroidal anti-inflammatory drugs (NSAIDs) reduce the risks of AD and Parkinson's (PD) diseases' development [27,31-33]. Since then, neuroinflammation and microglia are a rich topic of research for neurodegenerative disease treatment and diagnosis. In these diseases, protein aggregates, such as $\mathrm{A} \beta$-amyloid deposits in $\mathrm{AD}$ or $\alpha$-synuclein in $\mathrm{PD}$, will also activate microglia $[34,35]$. The persistence of these signals leads, in the long term, to an uncontrolled and unregulated microglia activation with high secretion of inflammatory factors which, in turn, will actively participate to neuronal death, because these cells are particularly sensitive to oxidative stress [36].

For years, targeting microglia in neurodegenerative diseases consisted in attempts to decrease cell activation and interesting results were obtained in preclinical models of $\mathrm{AD}, \mathrm{PD}$, and amyotrophic lateral sclerosis (ALS) [37-41]. However, no clinical effects of anti-inflammatory treatment were observed in clinical trials [42-44]. According to the recent knowledge on microglia polarization, promoting M2-microglia phenotype may be a promising target, as shown by studies on preclinical models of stroke [45], TBI [46], AD [47], PD [48], ALS [49], and multiple sclerosis (MS) [50]. Nonetheless, targeting neuroinflammation in these diseases is even more complex and a regimen of anti-inflammatory treatments is also crucial. In fact, at the early stage of neurodegenerative diseases, microglia activation might exert a neuroprotective effect [51,52].

\section{Imaging of Activated Microglia}

Regarding this activated microglia involvement in neurodegenerative disorders, and its potential therapeutic impact [31-33], interest in the development of suitable imaging tools to investigate microglia as a relevant marker of neuronal damage and CNS activity [53] has risen in recent years. Thus, in vivo imaging of activated microglia can provide a non-invasive and reliable detection of early and localized neuroinflammation processes, thanks to the availability of several neuroimaging modalities. On one hand, MRI-based (magnetic resonance imaging) techniques for the detection of neuroinflammation have been developed, based on the macrophages' labelling by ultrasmall superparamagnetic iron oxide (USPIO) nanoparticles [54]. Targeting neuroinflammatory changes with USPIO has been used in the clinical setting, where no correlation was found between iron oxide-based enhancement and infarct size in human studies [55]. This approach reflects vascular integrity rather than microglial activation, and the specificity and accuracy of labelling strategies in molecular MRI remain to be validated. On the other hand, in vivo functional cerebral imaging of activated microglia has been widely explored by positron emission tomography (PET) molecular imaging, using sensitive radioactive probes targeting specific molecular mediators of the inflammation cascade (cell surface and mitochondrial receptors or transporters expressed in activated microglia). We will outline an 
overview of these molecular targets, focusing on their respective contribution for the understanding of microglial involvement in neurodegenerative diseases.

\section{18-kDa Translocator Protein (TSPO): The "Gold Standard" Molecular Target for Activated Microglia PET Imaging}

\subsection{TSPO}

The 18-kDa translocator protein (TSPO) is a hetero-oligomeric complex located on the outer mitochondrial membrane known to be involved in modulating immune response, in cholesterol transport, and in heme/steroid synthesis [56]. TSPO was first described as a peripheral benzodiazepine receptor (PBR), a secondary binding site for diazepam, but has been renamed to TSPO to reflect some of these cellular functions [57]. This protein was initially found in peripheral organs (i.e., kidneys, nasal epithelium, adrenal glands, lungs, and heart), but is also minimally expressed on microglia in healthy brains [58]. However, TSPO expression is dramatically upregulated during the microglia activation process. Its basal expression rises in several acute and degenerative disorders, including AD, PD, MS, Huntington's disease (HD) [59], and amyotrophic lateral sclerosis (ALS) [60]. As a result, TSPO has been considered a hallmark of neuroinflammation. Therefore, TSPO PET imaging has been used for both improving the knowledge regarding the role of neuroinflammation in CNS diseases and to assess the efficacy of novel anti-inflammatory therapeutic strategies. The most widely used TSPO PET radiopharmaceutical, namely ${ }^{11} \mathrm{C}-(\mathrm{R})-\mathrm{PK} 11195$, is an isoquinoline carboxamide developed in the early 1980s [61]. However, ${ }^{11} \mathrm{C}-(\mathrm{R})-\mathrm{PK} 11195$ 's clinical usefulness is narrowed by several major limitations, including the short half-life of carbon-11, a low brain bioavailability and a poor signal-to-noise ratio due to high nonspecific binding [62]. To counteract these drawbacks, there has been a great amount of effort toward the development of second-generation TSPO PET radiotracers [63-65], including ${ }^{18}$ F-FEDAA1106, ${ }^{11}$ C-PBR28, ${ }^{11}$ C-DPA-713, and ${ }^{18}$ F-DPA-714.

TSPO PET radioligands made it possible to characterize in vivo, in numerous preclinical and clinical studies, the neuroinflammatory component of neurodegenerative disorders its spatial distribution, its intensity, and its longitudinal evolution. Thus, TSPO PET imaging is, nowadays, widely recognized as a useful biomarker of activated microglia involvement in CNS disorders that assisted in the early detection of neuroinflammation, monitor the severity and progression of the neurodegenerative diseases, and help to consider the effectiveness of emerging CNS therapies aimed at decreasing neuroinflammation.

\subsection{TSPO Limitations as a Molecular Target for Activated Microglia PET Imaging}

Several drawbacks limit the ability of TSPO as PET imaging molecular target.

First, a genetic polymorphism in exon 4 of the TSPO gene ( $r s 6971)$ has been identified, resulting in an alanine-to-threonine substitution (A147T) [66,67]. This polymorphism affects the binding affinity properties of most of PET TSPO radiopharmaceuticals for their target. Sensitivity to TSPO polymorphism is variable depending on the tracer considered, resulting in a very large heterogeneity in PET images and their associated quantitative data [66]. Three distinct binder statuses have been identified: $\mathrm{HAB}$, high- (A/A; 70\%), $\mathrm{MAB}$, mixed- $(\mathrm{A} / \mathrm{T} ; \sim 21 \%)$, and $\mathrm{LAB}$, low-affinity binders (T/T; $\sim 9 \%$ ). Then, this polymorphism, and its consequent binder status, can be identified by genetic analysis allowing stratification of subjects, and can subsequently account for binder status in the quantification of TSPO PET studies using second-generation radiotracers [68]. However, in LAB patients, TSPO PET images are of significantly lower quality, and the clinical usefulness of this approach is, therefore, limited in these patients. Even if the conclusions of clinical studies performed only on HAB or MAB patients might be extended to a whole-patient population, at least in AD [69], this polymorphism makes more difficult the design of clinical trials based on TSPO PET imaging. A third-generation TSPO radioligand, namely ${ }^{11} \mathrm{C}$-ER176, sensitive to polymorphism in vivo but allowing quantification in LAB 
patients, has recently been proposed; nonetheless, the clinical relevance of this compound remains to be confirmed [70].

Secondly, the mathematical model usually applied to quantify a brain PET radioligand binding requires either serial blood samples or a reference region free of specific ligand binding. However, TSPO is distributed throughout the entire brain, even at very low density, and no clear reference region may exist in neurodegenerative diseases. However, the cerebellum was validated as a reference region for ${ }^{11}$ C-PBR28-TSPO binding in AD patients [71], but regarding differences between radiotracers' pharmacokinetics and the variety of TSPO distribution depending on the considered disease, it is necessary to independently validate a reference region for each radiotracer and for each disease.

A third concern for the meaning of this PET imaging approach is the multicellular expression of TSPO in the human brain. In addition to activated microglia, astroglial expression of TSPO, and, in the case of a disrupted blood brain barrier (BBB), on infiltrating cells of mononuclear-phagocyte lineage have been reported [72]. TSPO in vivo PET imaging does not strictly reflect the activation of microglial cells, but a broader inflammatory process [73]. The PET signal can also be disrupted by TSPO peripheral vascular endothelial cells' expression, which, together with TSPO radioligands' plasma protein binding, impacts a partial volume effect, especially for cortical areas close to large blood vessels. Thus, Rizzo et al. have studied the positive impact of considering a model that includes an additional irreversible compartment from the blood to the endothelium (vascular component) on the quantification of ${ }^{11} \mathrm{C}$-PBR28 data, compared to the standard two-tissue compartmental model (2TCM) [74]. Authors demonstrated that the inclusion of the vascular component in the kinetic model (2TCM-1K) provided a more precise and accurate quantification of ${ }^{11} \mathrm{C}-\mathrm{PBR} 28$ brain PET data. The estimates are more than three-fold smaller, have a higher time stability and are better correlated to brain mRNA TSPO expression with 2TCM-1K model compared to 2TCM [74].

Lastly, since the characterization of the different subpopulations of microglial cells toward different phenotypes (M1, neurotoxic vs. M2, neuroprotective, see Section 1), it has been challenging to identify and differentiate these subtypes and their related pro/anti-inflammatory roles for both physiopathological understanding and new therapeutic approach designs. While the advent of TSPO PET agents has enabled the distribution of activated microglia in the brain to be imaged in vivo, TSPO ligands bind to both M1 and M2 phenotypes. TSPO PET, therefore, provides a measure of activated microglia load without information related with its specific functional role in different diseases and brain areas $[75,76]$.

\section{Potential Alternative Molecular Targets for Activated Microglia Imaging}

Limitations of the TSPO, as described above, have led to the identification of other molecular targets to develop new tracers of activated microglia. Moreover, in order to fulfill the current clinician's expectancies regarding the microglial role in neurodegenerative diseases and associated potential novel therapeutic approaches, radiopharmaceuticals able to discriminate activated microglia according to their polarization from M1 to M2 phenotypes are, to date, highly expected. In this part, we summarize potential microglial imaging targets as follows: (1) Targets evaluated by PET in pre-clinical or clinical settings for imaging microglial cells within the CNS; (2) Targets that have been used for imaging inflammatory conditions by PET in peripheral disorders; and (3) Potential targets for which radioligands have not been tested/synthetized yet. We will also pay particular attention to the potential interest of these targets to discriminate microglia subtypes (see Table 1). However, no in vivo study using any PET radioligands allowed the study of only one subpopulation of microglia. Targeting these molecules for PET imaging of M1 or M2 microglia requires further exploration.

\subsection{Molecular Targets Evaluated in CNS Diseases}

Table 1 summarizes candidate microglial imaging targets, for which dedicated PET radiopharmaceuticals have been developed and evaluated in pre-clinical and/or clinical CNS settings. 
Table 1. Activated microglia molecular targets with current applications for central nervous systems (CNS) disorders' positron emission tomography (PET) exploration.

\begin{tabular}{|c|c|c|c|c|c|c|}
\hline Target & Cellular Localization & Cellular Expression & Functions & M1/M2 Expression & Applications & References \\
\hline $\operatorname{cox}$ & Cytoplasmic enzyme & Microglia, neurons & Prostaglandins synthesis & $\begin{array}{l}\text { No data on microglia } \\
\text { subtypes expression }\end{array}$ & $\begin{array}{l}\text { COX-1 PET tracer: pre-clinical study on } \\
\text { animal model of AD COX-2 PET in rat } \\
\text { models of neuroinflammation }\end{array}$ & {$[77,78]$} \\
\hline CB2R & $\begin{array}{l}\text { G-protein-coupled } \\
\text { receptor }\end{array}$ & $\begin{array}{l}\text { Microglia, astrocytes, } \\
\text { microvascular } \\
\text { endothelial cells }\end{array}$ & $\begin{array}{l}\text { Inhibition of } \\
\text { pro-inflammatory cytokines' } \\
\text { (IL-1, TNF- } \alpha \text { ) release } \\
\text { Activation of } \\
\text { anti-inflammatory cytokines' } \\
\text { (IL-4, IL-10) release } \\
\end{array}$ & $\begin{array}{l}\text { No data on microglia } \\
\text { subtypes expression }\end{array}$ & $\begin{array}{l}{ }^{11} \mathrm{C}-\mathrm{NE} 40: \text { in human study in AD vs. } \\
\text { control patients (no increase of ligand } \\
\text { binding in AD patients) Other ligands: } \\
\text { preclinical studies such as brain uptake } \\
\text { in healthy rodent or post-mortem } \\
\text { binding in human ALS brain }\end{array}$ & {$[79,80]$} \\
\hline P2X7R & $\begin{array}{l}\text { Cation-permeable ion } \\
\text { channel receptor }\end{array}$ & $\begin{array}{l}\text { Microglia, macrophages, } \\
\text { astrocytes, Schwann cells }\end{array}$ & $\begin{array}{l}\text { Activation of } \\
\text { pro-inflammatory cytokines' } \\
\text { (IL-1 } \beta \text { ) and ROS release }\end{array}$ & $\begin{array}{l}\text { Potentially specific of } \\
\text { M1 subtypes }\end{array}$ & $\begin{array}{l}\text { In vivo preclinical study on } \\
\text { LPS-induced neuroinflammation (rat) }\end{array}$ & {$[81,82]$} \\
\hline$\beta$-glucuronidase & Lysosomal enzyme & Microglia, astrocytes, neurons & Anti-inflammatory effects & $\begin{array}{l}\text { No data on microglia } \\
\text { subtypes expression }\end{array}$ & $\begin{array}{l}\text { In vivo preclinical study on an } \\
\text { encephalitis rat model }\end{array}$ & [83] \\
\hline A2AR & $\begin{array}{l}\text { G-protein-coupled } \\
\text { receptor }\end{array}$ & Microglia, astrocytes, neurons & Anti-inflammatory effects & $\begin{array}{l}\text { No data on microglia } \\
\text { subtypes expression }\end{array}$ & In human study on PD and MS & {$[84,85]$} \\
\hline$\alpha 4 \beta 2$ nAChR & $\begin{array}{l}\text { Pentameric nicotinic } \\
\text { receptor }\end{array}$ & Microglia, neurons & $\begin{array}{l}\text { Anti-inflammatory effects } \\
\text { (cholinergic anti-inflammatory } \\
\text { pathway) }\end{array}$ & $\begin{array}{l}\text { No data on microglia } \\
\text { subtypes expression }\end{array}$ & $\begin{array}{l}\text { Preclinical study on neuroinflammation } \\
\text { induced by cerebral ischemia (rat) }\end{array}$ & {$[86]$} \\
\hline MMPs & $\begin{array}{l}\text { Immature enzymes are } \\
\text { cytoplasmic and secreted } \\
\text { and activated } \\
\text { extracellularly }\end{array}$ & $\begin{array}{l}\text { Microglia, neurons, } \\
\text { astrocytes, oligodendrocytes }\end{array}$ & $\begin{array}{l}\text { CNS development including } \\
\text { neurogenesis, myelogenesis, } \\
\text { and axonal guidance. }\end{array}$ & $\begin{array}{l}\text { No data on microglia } \\
\text { subtypes expression }\end{array}$ & $\begin{array}{l}\text { In vivo preclinical studies on a rat } \\
\text { model of stroke }\end{array}$ & {$[87-89]$} \\
\hline
\end{tabular}

A2AR: adenosine receptor 2A; CB2R: cannabinoid receptor type 2; COX: cyclooxygenase; nAChR: nicotinic acetylcholine receptor; P2X7R: purinergic receptor 2 ion channel receptor; MMP:

matrix metalloproteinases; IL: interleukin; TNF- $\alpha$ : tumor necrosis factor- $\alpha$; ROS: reactive oxygen species; LPS: lipopolysaccharide; M1: Classically or pro-inflammatory activated microglia;

M2: alternative or anti-inflammatory microglial cells; AD: Alzheimer's disease; PD: Parkinson's disease; MS: multiple sclerosis; ALS: amyotrophic lateral sclerosis 


\subsubsection{Cyclooxygenase (COX)}

Cyclooxygenase is an enzyme producing important biological mediators, including prostaglandins, which are involved in the regulation of neuroinflammatory process in connection with neurodegenerative diseases [90-92].

Among the different COX isoforms characterized, COX-1 is classically described as a constitutively expressed house-keeping enzyme, whereas COX-2 is an inflammatory inducible isoform, mainly expressed in response to neuroinflammation [93]. COX-1 immunoreactivity is enriched in the midbrain, pons, and medulla [94], whereas COX-2 immunoreactivity prevails in neurons and glial cells of the hippocampus, hypothalamus, and amygdala $[95,96]$. COX-2 is, therefore, considered as a key player in the pathophysiology of $\mathrm{AD}, \mathrm{PD}[97,98]$, and has been identified as a molecular target of interest for pharmacological design of selective ligands for both therapy and molecular imaging. Thus, highly-selective COX-2 radioligands, such as ${ }^{11} \mathrm{C}$-Celecoxib [99] or ${ }^{11} \mathrm{C}-$ Rofecoxib [77], have been evaluated to explore microglial activation by PET, but to date this approach remains unsuccessful, due to either non-specific bindings or low in vivo sensitivity of these radioligands $[100,101]$. In this context, the development of a selective COX-1 imaging probe has regained interest. The ${ }^{11} \mathrm{C}$-ketoprofen methyl ester $\left({ }^{11} \mathrm{C}-\mathrm{KTP}-\mathrm{Me}\right)$ has been evaluated in rodent models of focal neuroinflammation (intrastriatal injection of lipopolysaccharide or quinolinic acid), and exhibited striatal accumulation corresponding to the early phase of microglia activation (from six hours and at day 1 after the lesion) [102]. In contrast, the time course of striatal accumulation of ${ }^{11}$ C-PK11195, the gold-standard TSPO PET radioligand, started later and lasted up to 14 days afterward, corresponding to changes in activation of both microglia and astrocytes. This finding suggests the high specificity of cellular expression of COX-1 within microglia, during an acute neuroinflammatory process, and its ability to be evidenced by PET in vivo. More recently, the same group used ${ }^{11} \mathrm{C}-\mathrm{KTP}-\mathrm{Me}$ to investigate COX-1 involvement in amyloid precursor protein transgenic (APPSWE2576) mice, an animal model of AD [78]. PET images of $(S){ }^{-11} \mathrm{C}-\mathrm{KTP}-\mathrm{Me}$ specifically detected and clearly visualized the changes in COX-1 expression in activated microglia concomitantly to the formation of amyloid plaques in amyloid peptide precursor-transgenic mice (APP-Tg) mice. These preclinical data suggest that PET imaging of COX-1 with (S)- ${ }^{11} \mathrm{C}-\mathrm{KTP}-\mathrm{Me}$ could be a promising approach for monitoring activated microglia in CNS diseases, including AD.

\subsubsection{Cannabinoid Receptor}

While the cannabinoid receptor type 1 (CB1R) is constitutively the most abundantly expressed G-protein-coupled receptor in the human brain [103], the inducible isoform, namely cannabinoid receptor type 2 (CB2R), is barely detectable in the healthy brain [104]. Low levels of CB2R expression have been found in microglial cells [104,105], in human fetal astrocytes [106], and in human cerebral microvascular endothelial cells [107]. Nonetheless, several studies reported an upregulation of CB2R on activated microglial cells in pathological conditions, including MS, ALS, PD, or AD [105,108-110]. Moreover, selective CB2R activation results in a decrease of microglial activation in HD and ALS transgenic mouse models and appears to be effective in reducing neurodegeneration $[109,110]$. Neuroprotective effects of CB2 agonists are associated with suppression of microglia activation via inhibiting the release of neurotoxic factors and by decreasing neuronal cell damage in cell or tissue culture models [111]. These observations suggest that therapeutic modulation of CB2R may be a new promising treatment for neuropathogenic disorders characterized by a neuroinflammatory component. Recent findings have indicated that nicotine attenuates $A \beta$-induced microglial activation by shifting microglial M1 to M2 state, and cannabinoid CB2R mediates the process, thereby suggesting the CB2R involved in microglia polarization shift [112]. Several CB2R selective ligands have been developed over the past years [113] and the preliminary clinical evaluation with ${ }^{11} \mathrm{C}-\mathrm{NE} 40$ showed appropriate fast brain kinetics in the healthy human brain [114]. However, ${ }^{11} \mathrm{C}-\mathrm{NE} 40$ has not succeeded in highlighting microglial activation in AD subjects as compared to healthy controls. In 2015, Slavik et al. reported a novel carbon-11 radiolabeled tracer ${ }^{11} \mathrm{C}-\mathrm{RS}-016$ for CB2R imaging, which showed higher specific binding in postmortem ALS patient spinal cord tissues [79,80]. Since then, several other recently 
synthetized radiotracers are under preclinical investigations and seem to offer promising prospects for imaging CB2R expression [115-117].

\subsubsection{Purinergic Ion Channel Receptor}

Purinergic ion channel receptor (P2X) is a large family of receptors distributed in a wide variety of tissue [118]. Among them, P2X7 receptor (P2X7R) are expressed both peripherally and in the CNS, especially in microglia, astrocytes and Schwann cells [119]. P2X7R activation is associated with production of pro-inflammatory cytokines (IL-1 $\beta$ ) and ROS by peripheral macrophages, as well as microglia or astrocytes [120,121]. Moreover, P2X7R expression is increased in microglia in animal models of neurodegenerative diseases, such as AD [122], ALS [123], or HD [124]. Recently, P2X7R has been proposed as a marker of M1 microglia. Indeed, in a mouse ALS model, P2X7R inhibition led to a diminution of microgliosis associated with a decrease of M1 (IL-1 $\beta$ ) and an increase of M2 (IL-10) markers, leading authors to consider P2X7R as a potential maker of M1 microglia in ALS [125]. Involvement of P2X7R in microglia M1 polarization has recently been confirmed in vitro as P2X7R inhibition avoid M1 microglia polarization in ischaemic conditions [126]. Nevertheless, in vitro, P2X7R expression is also reported in M2 polarized macrophages and might so play a role in inflammation resolution [127].

The first candidate was the P2X7R antagonist A-740003, showing a high affinity and selectivity for the receptor. Preclinical in vivo study of ${ }^{11} \mathrm{C}-\mathrm{A}-740003$ showed little uptake in rat brains [81]. More recently, two other P2X7R antagonists has been radiolabeled and used in preclinical models. ${ }^{11} \mathrm{C}-\mathrm{JNJ}-54173717$ was shown to cross the BBB in rats and to have a higher binding in rat striatum injected with a viral vector expressing human P2X7R than in control rats. This compound was also used in monkeys and showed a specific binding to P2X7R, as the concomitant use of the JNJ-42253432, a P2X7R antagonist, completely block the brain fixation of the radiolabeled compound [128]. Anyway, the use of ${ }^{11} \mathrm{C}-J \mathrm{NJ}-54173717$ in a model of neuroinflammation has to be performed in order to validate its utilization as a marker of activated microglia. The other molecule recently tested is the GSK1482160, a strong P2X7R antagonist, evaluated in a phase 1 clinical study with a good BBB penetration [129]. The GSK1482160 has, thus, been labelled with carbon-11, and then evaluated in mice treated by LPS as a model of neuroinflammation, showing a significate increase of ${ }^{11} \mathrm{C}$-GSK1482160 binding in treated mouse brains vs. control [82]. Therefore, ${ }^{11}$ C-GSK1482160 appears as a promising radioligand of $\mathrm{P} 2 \mathrm{X} 7 \mathrm{R}$, as a marker of neuroinflammation.

\subsection{4. $\beta$-Glucuronidase}

$\beta$-Glucuronidase is a lysosomal enzyme involved both in the hydrolysis of glycosaminoglycans on the cell surface and in the degradation of the extracellular matrix. Several studies have reported an increase of $\beta$-glucuronidase expression by activated microglia into the extracellular space at the site of neuroinflammation $[130,131]$. Elevated levels of $\beta$-glucuronidase have been reported in the temporal cortex of $\mathrm{AD}$ patients and in the putamen of HD patients [132] and, thus, constituting a biomarker of neuroinflammation in relation with neurodegenerative diseases. Antunes et al. [83] have designed a PET tracer for $\beta$-glucuronidase imaging, namely ${ }^{18} \mathrm{~F}$-FEAnGA, that, despite a moderate brain uptake, succeeded in detecting an increased release of $\beta$-glucuronidase during neuroinflammation in an encephalitis rat model.

\subsubsection{Adenosine Receptor 2A}

Adenosine receptors belong to the purinergic G-coupled family receptors and are involved in inflammatory processes. Microglia express several types of adenosine receptors (A1, A2A, A2B, A3). Among them, the $2 \mathrm{~A}$ adenosine receptor (A2AR) seems to have an important implication in neurodegeneration [133], is overexpressed in vitro in activated microglia, and is also involved in the regulation of microglia activation $[134,135]$. A2AR has been considered an interesting target of activated microglia. 
Several tracers of A2AR have been synthetized $\left({ }^{11} \mathrm{C}\right.$-TMSX, ${ }^{11} \mathrm{C}$-preladenant, $\left.{ }^{18} \mathrm{~F}-\mathrm{FESCH}\right)$ and clinical studies have been performed with the ${ }^{11} \mathrm{C}$-TMSX $[84,136,137] .{ }^{11} \mathrm{C}-\mathrm{TMSX}$ showed that A2AR is increased in MS patients, in association with neuroinflammation, with a binding correlated with the severity of symptoms and the loss of cerebral tissue[85]. However, in PD patients, the uptake of this tracer is not related to neuroinflammation, but to neuronal regulation [84]. A2AR are expressed both in neurons and astrocytes but, regarding their brain distribution, they are strongly expressed in the striatum (post-synaptic neurons) $[84,138,139]$. This striatal neuronal expression probably explains results obtained in PD patients [84]. However, A2AR's increase in other brain areas may be relevant to follow brain inflammation elsewhere than in the striatum and might be therefore an interesting tool in neurodegenerative diseases such as MS.

\subsubsection{Nicotinic Acetylcholine Receptors $\alpha 4 \beta 2$}

Nicotinic acetylcholine receptors (nAChR) are pentameric ligand gated ion channels. In the brain, several subtypes of $n A C h R$ have been identified and, among them, the heteromeric $\alpha 4 \beta 2$ is one of the most abundant. $\alpha 4 \beta 2$ receptor expression in microglia is not well characterized yet. The $2{ }^{-18}$ F-fluoro-A85380 compound has been synthetized in order to follow $\alpha 4 \beta 2$ 's expression in neurodegenerative diseases [140]. Ex vivo studies with this tracer showed a decrease of binding in brain sections from AD patients [141], making this radiotracer a tool to follow the death of cholinergic neurons in neurodegenerative diseases. More recently, Martín et al. [86] used 2- ${ }^{18}$ F-fluoro-A85380 as a marker of neuroinflammation in a model of cerebral ischemia. Their results showed an uptake of this tracer similar to the one of PK11195 (for TSPO PET imaging), confirming the inflammatory expression of $\alpha 4 \beta 2$ in this model. Moreover, authors confirmed by immunohistochemistry the overexpression of $\alpha 4 \beta 2$ in microglia and astrocytes. Nonetheless, this overexpression of $\alpha 4 \beta 2$ in activated microglia is not well characterized yet and the neuronal expression of $\alpha 4 \beta 2$ is a limiting factor for the use of the nAChR tracer to follow microglia activation in vivo.

\subsubsection{Matrix Metalloproteinases}

Matrix metalloproteinases (MMPs) are a family of endopeptidases able to degrade the components of the extracellular matrix (collagen, gelatin, elastin) and are involved in tissue remodeling and degradation. Several subtypes of MMPs have been identified and their expression is enhanced by pro-inflammatory signals, such as cytokines (IL-1 $\beta, T N F \alpha$ ) or LPS. MMPs are associated in the CNS to excitotoxicity, neuronal damage, and BBB disruption, but also to the progression of neurodegenerative diseases $[142,143]$. Several tracers of MMPs or specific to one MMPs subtype have been synthetized in the last years.

Among them, the ${ }^{18} \mathrm{~F}-\mathrm{BR}-351$, derived from a non peptidic MMP inhibitor, was used in a rat model of stroke by transient middle cerebral artery occlusion (tMCAo) $[88,144]$. In this study, PET imaging of MMPs and TSPO were performed with the ${ }^{18} \mathrm{~F}-\mathrm{BR}-351$ and the ${ }^{18} \mathrm{~F}-\mathrm{DPA} 714$, respectively. Authors showed time course expression of MMPs and TSPO following tMCAo by PET imaging and confirmed the expression of MMP-9 in microglia in the infarct brain part by immunofluorescence. The same compound has very recently been used in a mice model of gliomas [145]. In parallel, other MMPs inhibitors, specific of one or several MMPs, have been labeled with ${ }^{18} \mathrm{~F}$ or $11 \mathrm{C}$ and showed brain uptake in small rodent biodistribution. These tracers have not been tested in a pathological model yet [146,147].

\subsection{Molecular Targets Evaluated in Other Inflammatory Diseases}

Even if not tested for microglia imaging yet, the molecular targets cited here might be promising for PET microglia imaging (Table 2). For these targets, PET ligands have been developed and tested in peripheral inflammatory conditions (i.e., macrophages expression). Some of these targets could be specific to the M1 or M2 phenotypes, but this specificity has never been demonstrated by in vivo imaging. Furthermore, the capacity of their ligands to cross the BBB must be studied before any application related to microglia activation. 
Table 2. Proposed alternative microglia molecular targets

\begin{tabular}{|c|c|c|c|c|c|c|}
\hline Target & Cellular Localization & Cellular Expression & Functions & M1/M2 Expression & Applications & References \\
\hline iNOS & Cytoplasmic enzyme & $\begin{array}{l}\text { Microglia, macrophages, } \\
\text { astrocytes }\end{array}$ & $\begin{array}{l}\text { Immune innate response: NO } \\
\text { production by immune cells }\end{array}$ & $\begin{array}{l}\text { Potentially specific of } \\
\text { M1 phenotype }\end{array}$ & $\begin{array}{l}\text { In human study in healthy } \\
\text { volunteers with endotoxin } \\
\text { administration in one lung }\end{array}$ & {$[148,149]$} \\
\hline FR $\beta$ & Surface receptor & Microglia & $\begin{array}{l}\text { Captation and internalization of } \\
\text { folic acid }\end{array}$ & $\begin{array}{l}\text { Potentially specific of } \\
\text { M2 phenotype }\end{array}$ & $\begin{array}{l}\text { In vivo preclinical study on models } \\
\text { of peripheral inflammation (paw } \\
\text { inflammation, rheumatoid arthritis) }\end{array}$ & {$[150,151]$} \\
\hline IDO-1 & Cytoplasmic enzyme & Microglia, neurons & Tryptophan catalization & $\begin{array}{l}\text { No data on microglia } \\
\text { subtypes expression }\end{array}$ & $\begin{array}{l}\text { Compound labelled but not } \\
\text { evaluated in preclinical study }\end{array}$ & [152] \\
\hline KMO & Cytoplasmic enzyme & Microglia, macrophages & Tryptophan catalization & $\begin{array}{l}\text { No data on microglia } \\
\text { subtypes expression }\end{array}$ & No PET tracer developed yet & [153] \\
\hline P2Y12R & $\begin{array}{l}\text { Purinergic } \\
\text { G-protein-coupled receptor }\end{array}$ & Microglia & Involved in platelet agregation & $\begin{array}{l}\text { Potentially specific of } \\
\text { M2 phenotype }\end{array}$ & No PET tracer developed yet & {$[154,155]$} \\
\hline
\end{tabular}

COX: cyclooxygenase; FR $\beta$ : folate receptor $\beta$; IDO-1: indoleamine 2,3-dioxygenase 1; iNOS: inducible nitric oxide synthase; KMO: kynurenine-3-monooxygenase; MMPs: matrix metalloproteinases; P2Y12: purinergic ion channel Y12. 


\subsubsection{Inducible Nitric Oxide Synthase}

Nitric oxide (NO) is a ubiquitous cellular messenger, involved in several physiological processes in peripheral systems, but also in the brain. NO production by immune cells (macrophages, microglia) participates in innate responses, and especially in cell death, through the inhibition of mitochondrial respiration [156,157]. The inducible nitric oxide synthase (iNOS) that produces $\mathrm{NO}$ is not expressed in the brain, or at very low concentration, in physiological conditions but, in inflammatory conditions, iNOS is overexpressed in microglia and astrocytes [158]. iNOS is also considered as specific of a M1 phenotype in both macrophages and microglia $[148,159]$. iNOS macrophage's expression in inflammatory condition has been assessed in vivo using the ${ }^{18}$ F6-(2-fluoropropyl)-4-methyl-pyridin-2-amine, both in mouse and human. It was tested in vivo in a mouse model of iNOS induction by LPS injection. Results showed a significantly higher uptake of the tracer in the lung of LPS mice vs. control [160]. More recently, the same compound, renamed ${ }^{18} \mathrm{~F}-\mathrm{NOS}$, was used in healthy volunteers for the first in-human evaluation. A comparison was made on subjects after endotoxin administration in the right lung, which evidenced an increase of $30 \%$ of ${ }^{18} \mathrm{~F}-\mathrm{NOS}$ intake in this lung vs. the left one [149].

\subsubsection{Folate Receptor $\beta$}

Folate receptor (FR) is a family of four receptor subtypes $(\alpha, \beta, \gamma$ or $\delta)$ that bind folic acid. FR $\beta$ expression is described in activated macrophages in the model of inflammatory diseases (rheumatoid arthritis, Crohn's disease, etc.) [161]. FR $\beta$ is not expressed in quiescent or resting microglia. As FR $\beta$ award macrophages to internalize molecules derived from folic acid, the development of tracers derived from folic acid could allowed the following of activated macrophages and microglia [162]. Moreover, in vitro studies showed that FR $\beta$ is specifically expressed by M2 polarized macrophages [163]. In an in vivo rat model of restraint stress MacDowell et al. [164] used FR $\beta$ as a specific marker of M2 microglia. Nonetheless, this seems to be the only publication describing FR $\beta$ as a specific marker of M2 microglia. On the other hand, a study on macrophages isolated from mice after bacterial infection showed a correlation between FR $\beta$ expression, ROS production, and TNF $\alpha$ secretion, both of which were more specific to an M1 phenotype [165]. FR $\beta$ might be involved in microglia M1/M2 polarization, but extended studies on this receptor expression in microglial cells are still required to assess its interest for PET microglia imaging.

Kularatne et al. [150] developed two conjugated molecules derived from folic acid for FR $\beta$ PET imaging: $4^{-18} \mathrm{~F}$-fluorophenylfolate and ${ }^{68} \mathrm{Ga}$-DOTA-folate. They tested these compounds to follow macrophages activation in a model of paw inflammation in the rat and showed that uptake of both radiotracers was increased in the inflamed paw. Another compound, ${ }^{18}$ F-fluoro-PEG-folate, also gave interesting results in a rat model of rheumatoid arthritis [151]. If no clinical studies using PET tracers of FR $\beta$ have been performed yet, a single-photon emission computed tomography (SPECT) tracer, ${ }^{9 \mathrm{~m}} \mathrm{Tc}-\mathrm{EC} 20$, was used on patients with rheumatoid arthritis [166].

\subsection{Potential Targets of Microglia Activation}

In this part, we regroup targets expressed in activated microglia but for which no radiotracer has been synthetized or tested yet (Table 2). More investigations are needed to assess in vivo expression of these targets in activated microglia.

5.3.1. Enzymes of the Kynurenine Pathway: Indoleamine 2,3-dioxygenase-1 and Kynurenine-3-monooxygenase

The kynurenine pathway (KP) mediates the tryptophan catalyzation in both periphery and CNS. KP is stimulated by inflammatory molecules, such as IFN- $\gamma$, and, in the brain, products of KP have been identified to be neuroprotective (picolinic acid, kynurenic acid) or neurotoxic (quinolinic acid, 3-hydroxykinurenine) [167]. Indoleamine 2,3-dioxygenase-1 (IDO-1) is one of the limiting 
enzymes of $\mathrm{KP}$, is expressed in immune peripheral cells and, in the brain, in microglia cells, astrocytes, and neurons. IDO-1 is strongly induced in primary microglial cells by LPS and IFN- $\gamma$ [168] and is overexpressed during neurodegenerative disease processes, such as for MS [169], AD [170], and PD [171]. Furthermore, in AD patient brains, IDO-1 immunoreactivity is increased in microglia and astrocytes [172], making IDO-1 a serious candidate to follow microglia activation in vivo.

Several analogues of tryptophan have been synthetized, labelled, and used in vitro or in animal models with tumor grafts [173]. These molecules are promising to follow tryptophan metabolism but are not specific of IDO expression. Huang et al. [152] used another approach to develop a tracer of IDO- 1 by using IDOL5, a strong antagonist of IDO-1. They successfully labeled IDOL 5 with ${ }^{18} \mathrm{~F}$ but this potential tracer has not been evaluated neither in in vitro nor in vivo tests so far.

More recently, the kynurenine-3-monooxygenase (KMO), another enzyme involved in KP, has been described as regulated by proinflammatory cytokine signals. In vivo, in the brain, KMO is predominantly expressed in microglia [153] and is involved in the regulation of quinolinic acid production. KMO is overexpressed, in vitro, in macrophages and microglia activated by IFN- $\gamma$. KMO is also increased by LPS treatment in rat brains. KMO could be an interesting target to follow microglia activation, but its characterization requires more investigation.

\subsubsection{P2Y12 Receptor}

The P2Y12 receptor (P2Y12R), a purinergic G-protein-coupled receptor, is exclusively expressed in microglia in the CNS. This receptor is not found in peripheral macrophages and is, thus, a good marker to distinguish resident microglia from infiltrated macrophages [174]. Expression of P2Y12R in activated microglia is still hard to qualify but showed that in vitro M2-polarized microglia overexpressed P2Y12R [155]. On the other hand, pathological conditions, such as AD, are associated with a decrease of P2Y12R expression in microglia, notably near the plaques or lesion sites, compared to microglial cells in other brain areas [174,175]. This decrease of P2Y12R expression in such inflammatory conditions (i.e., the presence of proteins able to activate the toll like receptor 4 (TLR4) pathway) may be associated with an increase of M1, and a diminution of M2, microglial cells in these areas. This hypothesis is supported by the P2Y12R expression in microglia of brains with parasite infections, a condition known to privilege M2 polarization of immune cells [155]. P2Y12R may, thus, be a promising target of M2 microglia but further studies are needed to confirm its in vivo expression in this microglia subpopulation.

\section{Conclusions}

It is, to date, broadly recognized that neuroinflammation, and in particular microglia activation, plays a crucial role in various brain disorders, from acute (stroke, TBI) to chronic (neurodegenerative disorders) ones. Initially, the large body of post mortem evidence of activated microglia in various CNS conditions led most of the authors to consider the microglial cells' shift from sensing activity to a reactive state as a deleterious process. This microglial activation has been first assessed in vivo thanks to PET radioligands targeting TSPO. Polymorphism and multicellular expression of TSPO, as well as the lack of a specific brain region of negative control, led to identifying other molecular biomarkers of activated microglia that would likely be complementary to TSPO PET imaging. Among the targets of interest summarized in the present review, P2X7 receptor appears to be the most promising one regarding: (1) its implication in neurodegenerative diseases' pathophysiology, highlighted by numerous current clinical trials aiming at evaluating P2X7 antagonists in CNS indications [176]; (2) the recent development of efficient dedicated radiopharmaceuticals that are currently coming available for clinical trials; (3) its implication on M1 microglial polarization. Thus, a multi-targets approach for PET imaging of microglia activation, combining TSPO radiopharmaceuticals with new probes specific of P2X7 expression may help to characterize the involvement of neuroinflammation over the CNS disorder's progression, as well as to follow the effects of clinical treatments on microglia polarization. 
Acknowledgments: This study was supported by the French National Agency for Research ("Investissements d'Avenir" n ${ }^{\circ}$ ANR-11-LABX-0018-01), IRON; and the European Union's Seventh Framework Programme (FP7/2004-2013) under grant agreement $\mathrm{n}^{\circ} 278850$ (INMiND).

Author Contributions: Claire Tronel wrote the manuscript, prepared the tables and had a major role in the selection and summary of published literature to which reference is made in this review. Bérenger Largeau wrote the manuscript and participated in the selection and summary of published literature to which reference is made in this review. Anne-Claire Dupont contributed in improving the article, notably according to the reviewers' comments and participated in the selection and summary of published literature to which reference is made in this review. Maria-Joao Santiago Ribeiro and Denis Guilloteau revised the paper. Nicolas Arlicot conceived the idea and designed the paper.

Conflicts of Interest: The authors declare no conflict of interest.

\section{References}

1. Nissl, F. Über einige Beziehungen zwischen Nervenzellerkrankungen und gliösen Erscheinungen bei verschiedenen Psychosen. Arch. Psychiatr. 1899, 32, 656-676.

2. Del Rio-Hortega, P. Studies on neuroglia: Glia with very few processes (oligodendroglia) by PÃ-o del RÃ-o-Hortega. 1921. Clin. Neuropathol. 2012, 31, 440-459. [PubMed]

3. Saijo, K.; Glass, C.K. Microglial cell origin and phenotypes in health and disease. Nat. Rev. Immunol. 2011, 11, 775-787. [CrossRef] [PubMed]

4. Ginhoux, F.; Prinz, M. Origin of microglia: Current concepts and past controversies. Cold Spring Harb. Perspect. Biol. 2015, 7, a020537. [CrossRef] [PubMed]

5. Olah, M.; Biber, K.; Vinet, J.; Boddeke, H.W.G.M. Microglia phenotype diversity. CNS Neurol. Disord. Drug Targets 2011, 10, 108-118. [CrossRef] [PubMed]

6. Savchenko, V.L.; McKanna, J.A.; Nikonenko, I.R.; Skibo, G.G. Microglia and astrocytes in the adult rat brain: Comparative immunocytochemical analysis demonstrates the efficacy of lipocortin 1 immunoreactivity. Neuroscience 2000, 96, 195-203. [CrossRef]

7. Lawson, L.J.; Perry, V.H.; Dri, P.; Gordon, S. Heterogeneity in the distribution and morphology of microglia in the normal adult mouse brain. Neuroscience 1990, 39, 151-170. [CrossRef]

8. Robillard, K.N.; Lee, K.M.; Chiu, K.B.; MacLean, A.G. Glial cell morphological and density changes through the lifespan of rhesus macaques. Brain Behav. Immun. 2016, 55, 60-69. [CrossRef] [PubMed]

9. Pintado, C.; Revilla, E.; Vizuete, M.L.; Jiménez, S.; García-Cuervo, L.; Vitorica, J.; Ruano, D.; Castaño, A. Regional difference in inflammatory response to LPS-injection in the brain: Role of microglia cell density. J. Neuroimmunol. 2011, 238, 44-51. [CrossRef] [PubMed]

10. Grabert, K.; Michoel, T.; Karavolos, M.H.; Clohisey, S.; Baillie, J.K.; Stevens, M.P.; Freeman, T.C.; Summers, K.M.; McColl, B.W. Microglial brain region-dependent diversity and selective regional sensitivities to aging. Nat. Neurosci. 2016, 19, 504-516. [CrossRef] [PubMed]

11. Kreutzberg, G.W. Microglia: A sensor for pathological events in the CNS. Trends Neurosci. 1996, 19, 312-318. [CrossRef]

12. Nimmerjahn, A.; Kirchhoff, F.; Helmchen, F. Resting microglial cells are highly dynamic surveillants of brain parenchyma in vivo. Science 2005, 308, 1314-1318. [CrossRef] [PubMed]

13. Block, M.L.; Zecca, L.; Hong, J.-S. Microglia-mediated neurotoxicity: Uncovering the molecular mechanisms. Nat. Rev. Neurosci. 2007, 8, 57-69. [CrossRef] [PubMed]

14. Hanisch, U.-K.; Kettenmann, H. Microglia: Active sensor and versatile effector cells in the normal and pathologic brain. Nat. Neurosci. 2007, 10, 1387-1394. [CrossRef] [PubMed]

15. Czeh, M.; Gressens, P.; Kaindl, A.M. The yin and yang of microglia. Dev. Neurosci. 2011, 33, $199-209$. [CrossRef] [PubMed]

16. Ransohoff, R.M.; Perry, V.H. Microglial physiology: Unique stimuli, specialized responses. Annu. Rev. Immunol. 2009, 27, 119-145. [CrossRef] [PubMed]

17. Sanchez-Guajardo, V.; Febbraro, F.; Kirik, D.; Romero-Ramos, M. Microglia acquire distinct activation profiles depending on the degree of alpha-synuclein neuropathology in a rAAV based model of Parkinson's disease. PLoS ONE 2010, 5, e8784. [CrossRef] [PubMed]

18. Mosser, D.M.; Edwards, J.P. Exploring the full spectrum of macrophage activation. Nat. Rev. Immunol. 2008, 8, 958-969. [CrossRef] [PubMed] 
19. Michelucci, A.; Heurtaux, T.; Grandbarbe, L.; Morga, E.; Heuschling, P. Characterization of the microglial phenotype under specific pro-inflammatory and anti-inflammatory conditions: Effects of oligomeric and fibrillar amyloid-beta. J. Neuroimmunol. 2009, 210, 3-12. [CrossRef] [PubMed]

20. Chhor, V.; Le Charpentier, T.; Lebon, S.; Oré, M.-V.; Celador, I.L.; Josserand, J.; Degos, V.; Jacotot, E.; Hagberg, H.; Sävman, K.; Mallard, C.; Gressens, P.; Fleiss, B. Characterization of phenotype markers and neuronotoxic potential of polarised primary microglia in vitro. Brain Behav. Immun. 2013, 32, 70-85. [CrossRef] [PubMed]

21. Gordon, S.; Martinez, F.O. Alternative activation of macrophages: Mechanism and functions. Immunity 2010, 32, 593-604. [CrossRef] [PubMed]

22. Latta, C.H.; Sudduth, T.L.; Weekman, E.M.; Brothers, H.M.; Abner, E.L.; Popa, G.J.; Mendenhall, M.D.; Gonzalez-Oregon, F.; Braun, K.; Wilcock, D.M. Determining the role of IL-4 induced neuroinflammation in microglial activity and amyloid- $\beta$ using BV2 microglial cells and APP/PS1 transgenic mice. J Neuroinflamm. 2015, 12, 41. [CrossRef] [PubMed]

23. Lisi, L.; Stigliano, E.; Lauriola, L.; Navarra, P.; Dello Russo, C. Proinflammatory-activated glioma cells induce a switch in microglial polarization and activation status, from a predominant $\mathrm{M} 2 \mathrm{~b}$ phenotype to a mixture of M1 and M2a/B polarized cells. ASN Neuro 2014, 6, 171-183. [CrossRef] [PubMed]

24. Wilcock, D.M. Neuroinflammatory phenotypes and their roles in Alzheimer's disease. Neurodegener Dis. 2014, 13, 183-185. [CrossRef] [PubMed]

25. Graeber, M.B.; Streit, W.J. Microglia: Biology and pathology. Acta Neuropathol. 2010, 119, 89-105. [CrossRef] [PubMed]

26. Haga, S.; Akai, K.; Ishii, T. Demonstration of microglial cells in and around senile (neuritic) plaques in the Alzheimer brain. An immunohistochemical study using a novel monoclonal antibody. Acta Neuropathol. 1989, 77, 569-575. [CrossRef] [PubMed]

27. Breitner, J.C.; Baker, L.D.; Montine, T.J.; Meinert, C.L.; Lyketsos, C.G.; Ashe, K.H.; Brandt, J.; Craft, S.; Evans, D.E.; Green, R.C.; Ismail, M.S.; Martin, B.K.; Mullan, M.J.; Sabbagh, M.; Tariot, P.N. ADAPT Research Group Extended results of the Alzheimer's disease anti-inflammatory prevention trial. Alzheimers Dement. 2011, 7, 402-411. [CrossRef] [PubMed]

28. Lemarchant, S.; Dunghana, H.; Pomeshchik, Y.; Leinonen, H.; Kolosowska, N.; Korhonen, P.; Kanninen, K.M.; García-Berrocoso, T.; Montaner, J.; Malm, T.; et al. Anti-inflammatory effects of ADAMTS-4 in a mouse model of ischemic stroke. Glia 2016, 64, 1492-1507. [CrossRef] [PubMed]

29. Sun, W.; Liu, J.; Huan, Y.; Zhang, C. Intracranial injection of recombinant stromal-derived factor-1 alpha (SDF-1 $\alpha$ ) attenuates traumatic brain injury in rats. Inflamm. Res. 2014, 63, 287-297. [CrossRef] [PubMed]

30. Veltkamp, R.; Gill, D. Clinical trials of immunomodulation in ischemic stroke. Neurotherapeutics 2016, 13, 791-800. [CrossRef] [PubMed]

31. Vlad, S.C.; Miller, D.R.; Kowall, N.W.; Felson, D.T. Protective effects of NSAIDs on the development of Alzheimer disease. Neurology 2008, 70, 1672-1677. [CrossRef] [PubMed]

32. Chen, H.; Jacobs, E.; Schwarzschild, M.A.; McCullough, M.L.; Calle, E.E.; Thun, M.J.; Ascherio, A. Nonsteroidal antiinflammatory drug use and the risk for Parkinson's disease. Ann. Neurol. 2005, 58, 963-967. [CrossRef] [PubMed]

33. Gao, X.; Chen, H.; Schwarzschild, M.A.; Ascherio, A. Use of ibuprofen and risk of Parkinson disease. Neurology 2011, 76, 863-869. [CrossRef] [PubMed]

34. Stewart, C.R.; Stuart, L.M.; Wilkinson, K.; van Gils, J.M.; Deng, J.; Halle, A.; Rayner, K.J.; Boyer, L.; Zhong, R.; Frazier, W.A.; et al. CD36 ligands promote sterile inflammation through assembly of a Toll-like receptor 4 and 6 heterodimer. Nat. Immunol. 2010, 11, 155-161. [CrossRef] [PubMed]

35. Bamberger, M.E.; Harris, M.E.; McDonald, D.R.; Husemann, J.; Landreth, G.E. A cell surface receptor complex for fibrillar beta-amyloid mediates microglial activation. J. Neurosci. 2003, 23, 2665-2674. [PubMed]

36. Smith, J.A.; Das, A.; Ray, S.K.; Banik, N.L. Role of pro-inflammatory cytokines released from microglia in neurodegenerative diseases. Brain Res. Bull. 2012, 87, 10-20. [CrossRef] [PubMed]

37. Cui, Y.-Q.; Wang, Q.; Zhang, D.-M.; Wang, J.-Y.; Xiao, B.; Zheng, Y.; Wang, X.-M. Triptolide rescues spatial memory deficits and amyloid- $\beta$ aggregation accompanied by inhibition of inflammatory Responses and MAPKs activity in APP/PS1 transgenic mice. Curr. Alzheimer Res. 2016, 13, 288-296. [CrossRef] [PubMed] 
38. Takamura, R.; Watamura, N.; Nikkuni, M.; Ohshima, T. All-trans retinoic acid improved impaired proliferation of neural stem cells and suppressed microglial activation in the hippocampus in an Alzheimer's mouse model. J. Neurosci. Res. 2016, 95, 897-906. [CrossRef] [PubMed]

39. Yang, W.; Chen, Y.-H.; Liu, H.; Qu, H.-D. Neuroprotective effects of piperine on the 1-methyl-4-phenyl1,2,3,6-tetrahydropyridine-induced Parkinson's disease mouse model. Int. J. Mol. Med. 2015, 36, 1369-1376. [CrossRef] [PubMed]

40. Kim, C.; Ojo-Amaize, E.; Spencer, B.; Rockenstein, E.; Mante, M.; Desplats, P.; Wrasidlo, W.; Adame, A.; Nchekwube, E.; Oyemade, O.; et al. Hypoestoxide reduces neuroinflammation and $\alpha$-synuclein accumulation in a mouse model of Parkinson's disease. J Neuroinflamm. 2015, 12, 236. [CrossRef] [PubMed]

41. Goursaud, S.; Schäfer, S.; Dumont, A.O.; Vergouts, M.; Gallo, A.; Desmet, N.; Deumens, R.; Hermans, E. The anti-inflammatory peptide stearyl-norleucine-VIP delays disease onset and extends survival in a rat model of inherited amyotrophic lateral sclerosis. Exp. Neurol. 2015, 263, 91-101. [CrossRef] [PubMed]

42. Butchart, J.; Brook, L.; Hopkins, V.; Teeling, J.; Püntener, U.; Culliford, D.; Sharples, R.; Sharif, S.; McFarlane, B.; Raybould, R.; et al. Etanercept in Alzheimer disease: A randomized, placebo-controlled, double-blind, phase 2 trial. Neurology 2015, 84, 2161-2168. [CrossRef] [PubMed]

43. Turner, R.S.; Thomas, R.G.; Craft, S.; van Dyck, C.H.; Mintzer, J.; Reynolds, B.A.; Brewer, J.B.; Rissman, R.A.; Raman, R.; Aisen, P.S.; et al. A randomized, double-blind, placebo-controlled trial of resveratrol for Alzheimer disease. Neurology 2015, 85, 1383-1391. [CrossRef] [PubMed]

44. Cudkowicz, M.E.; Shefner, J.M.; Schoenfeld, D.A.; Zhang, H.; Andreasson, K.I.; Rothstein, J.D.; Drachman, D.B. Trial of celecoxib in amyotrophic lateral sclerosis. Ann. Neurol. 2006, 60, 22-31. [CrossRef] [PubMed]

45. He, Y.; Ma, X.; Li, D.; Hao, J. Thiamet G mediates neuroprotection in experimental stroke by modulating microglia/macrophage polarization and inhibiting NF-кB p65 signaling. J. Cereb. Blood Flow Metab. 2016. [CrossRef] [PubMed]

46. Wang, G.; Shi, Y.; Jiang, X.; Leak, R.K.; Hu, X.; Wu, Y.; Pu, H.; Li, W.-W.; Tang, B.; Wang, Y.; et al. HDAC inhibition prevents white matter injury by modulating microglia/macrophage polarization through the GSK3 $\beta /$ PTEN/Akt axis. Proc. Natl. Acad. Sci. USA 2015, 112, 2853-2858. [CrossRef] [PubMed]

47. Zhu, D.; Yang, N.; Liu, Y.-Y.; Zheng, J.; Ji, C.; Zuo, P.-P. M2 Macrophage transplantation ameliorates cognitive dysfunction in amyloid- $\beta$-treated rats through regulation of microglial polarization. J. Alzheimers Dis. 2016, 52, 483-495. [CrossRef] [PubMed]

48. Park, H.J.; Oh, S.H.; Kim, H.N.; Jung, Y.J.; Lee, P.H. Mesenchymal stem cells enhance $\alpha$-synuclein clearance via M2 microglia polarization in experimental and human parkinsonian disorder. Acta Neuropathol. 2016, 132, 685-701. [CrossRef] [PubMed]

49. Wang, Y.; Duan, W.; Wang, W.; di Wen, N.; Liu, Y.; Liu, Y.; Li, Z.; Hu, H.; Lin, H.; Cui, C.; et al. scAAV9-VEGF prolongs the survival of transgenic ALS mice by promoting activation of M2 microglia and the PI3K/Akt pathway. Brain Res. 2016, 1648, 1-10. [CrossRef] [PubMed]

50. Guglielmetti, C.; le Blon, D.; Santermans, E.; Salas-Perdomo, A.; Daans, J.; de Vocht, N.; Shah, D.; Hoornaert, C.; Praet, J.; Peerlings, J.; et al. Interleukin-13 immune gene therapy prevents CNS inflammation and demyelination via alternative activation of microglia and macrophages. Glia 2016, 64, 2181-2200. [CrossRef] [PubMed]

51. Hamelin, L.; Lagarde, J.; Dorothée, G.; Leroy, C.; Labit, M.; Comley, R.A.; de Souza, L.C.; Corne, H.; Dauphinot, L.; Bertoux, M.; et al. Early and protective microglial activation in Alzheimer's disease: A prospective study using 18F-DPA-714 PET imaging. Brain 2016, 139, 1252-1264. [CrossRef] [PubMed]

52. Hooten, K.G.; Beers, D.R.; Zhao, W.; Appel, S.H. Protective and toxic neuroinflammation in amyotrophic lateral sclerosis. Neurotherapeutics 2015, 12, 364-375. [CrossRef] [PubMed]

53. Politis, M.; Su, P.; Piccini, P. Imaging of microglia in patients with neurodegenerative disorders. Front. Pharmacol. 2012, 3, 96. [CrossRef] [PubMed]

54. Jander, S.; Schroeter, M.; Saleh, A. Imaging inflammation in acute brain ischemia. Stroke 2007, 38, 642-645. [CrossRef] [PubMed]

55. Nighoghossian, N.; Wiart, M.; Berthezene, Y. Novel applications of magnetic resonance imaging to image tissue inflammation after stroke. J. Neuroimaging 2008, 18, 349-352. [CrossRef] [PubMed]

56. Mukhin, A.G.; Papadopoulos, V.; Costa, E.; Krueger, K.E. Mitochondrial benzodiazepine receptors regulate steroid biosynthesis. Proc. Natl. Acad. Sci. USA 1989, 86, 9813-9816. [CrossRef] [PubMed] 
57. Papadopoulos, V.; Baraldi, M.; Guilarte, T.R.; Knudsen, T.B.; Lacapère, J.-J.; Lindemann, P.; Norenberg, M.D.; Nutt, D.; Weizman, A.; Zhang, M.-R.; et al. Translocator protein (18 kDa): New nomenclature for the peripheral-type benzodiazepine receptor based on its structure and molecular function. Trends Pharmacol. Sci. 2006, 27, 402-409. [CrossRef] [PubMed]

58. Banati, R.B. Visualising microglial activation in vivo. Glia 2002, 40, 206-217. [CrossRef] [PubMed]

59. Messmer, K.; Reynolds, G.P. Increased peripheral benzodiazepine binding sites in the brain of patients with Huntington's disease. Neurosci. Lett. 1998, 241, 53-56. [CrossRef]

60. Turner, M.R.; Cagnin, A.; Turkheimer, F.E.; Miller, C.C.J.; Shaw, C.E.; Brooks, D.J.; Leigh, P.N.; Banati, R.B. Evidence of widespread cerebral microglial activation in amyotrophic lateral sclerosis: An [11C](R)-PK11195 positron emission tomography study. Neurobiol. Dis. 2004, 15, 601-609. [CrossRef] [PubMed]

61. Le Fur, G.; Perrier, M.L.; Vaucher, N.; Imbault, F.; Flamier, A.; Benavides, J.; Uzan, A.; Renault, C.; Dubroeucq, M.C.; Guérémy, C. Peripheral benzodiazepine binding sites: Effect of PK 11195, 1-(2-chlorophenyl)-N-methyl-N-(1-methylpropyl)-3-isoquinolinecarboxamide. I. In vitro studies. Life Sci. 1983, 32, 1839-1847. [CrossRef]

62. Chauveau, F.; Boutin, H.; van Camp, N.; Dollé, F.; Tavitian, B. Nuclear imaging of neuroinflammation: A comprehensive review of [11C]PK11195 challengers. Eur. J. Nucl. Med. Mol. Imaging 2008, 35, 2304-2319. [CrossRef] [PubMed]

63. Dollé, F.; Luus, C.; Reynolds, A.; Kassiou, M. Radiolabelled molecules for imaging the translocator protein (18 kDa) using positron emission tomography. Curr. Med. Chem. 2009, 16, 2899-2923. [CrossRef] [PubMed]

64. Tang, D.; McKinley, E.T.; Hight, M.R.; Uddin, M.I.; Harp, J.M.; Fu, A.; Nickels, M.L.; Buck, J.R.; Manning, H.C. Synthesis and structure-activity relationships of 5,6,7-substituted pyrazolopyrimidines: Discovery of a novel TSPO PET ligand for cancer imaging. J. Med. Chem. 2013, 56, 3429-3433. [CrossRef] [PubMed]

65. Scarf, A.M.; Ittner, L.M.; Kassiou, M. The translocator protein (18 kDa): Central nervous system disease and drug design. J. Med. Chem. 2009, 52, 581-592. [CrossRef] [PubMed]

66. Owen, D.R.J.; Gunn, R.N.; Rabiner, E.A.; Bennacef, I.; Fujita, M.; Kreisl, W.C.; Innis, R.B.; Pike, V.W.; Reynolds, R.; Matthews, P.M.; et al. Mixed-affinity binding in humans with 18-kDa translocator protein ligands. J. Nucl. Med. 2011, 52, 24-32. [CrossRef] [PubMed]

67. Owen, D.R.; Yeo, A.J.; Gunn, R.N.; Song, K.; Wadsworth, G.; Lewis, A.; Rhodes, C.; Pulford, D.J.; Bennacef, I.; Parker, C.A.; et al. An 18-kDa translocator protein (TSPO) polymorphism explains differences in binding affinity of the PET radioligand PBR28. J. Cereb. Blood Flow Metab. 2012, 32, 1-5. [CrossRef] [PubMed]

68. Vivash, L.; O’Brien, T.J. Imaging Microglial Activation with TSPO PET: Lighting Up Neurologic Diseases? J. Nucl. Med. 2016, 57, 165-168. [CrossRef] [PubMed]

69. Fan, Z.; Okello, A.A.; Brooks, D.J.; Edison, P. Longitudinal influence of microglial activation and amyloid on neuronal function in Alzheimer's disease. Brain 2015, 138, 3685-3698. [CrossRef] [PubMed]

70. Ikawa, M.; Lohith, T.G.; Shrestha, S.; Telu, S.; Zoghbi, S.S.; Castellano, S.; Taliani, S.; da Settimo, F.; Fujita, M.; Pike, V.W.; et al. 11C-ER176, a radioligand for 18-kDa translocator protein (TSPO), has adequate sensitivity to robustly image all three affinity genotypes in human brain. J. Nucl. Med. 2016. [CrossRef]

71. Lyoo, C.H.; Ikawa, M.; Liow, J.-S.; Zoghbi, S.S.; Morse, C.L.; Pike, V.W.; Fujita, M.; Innis, R.B.; Kreisl, W.C. Cerebellum can serve as a pseudo-reference region in Alzheimer disease to detect neuroinflammation measured with PET radioligand binding to translocator protein. J. Nucl. Med. 2015, 56, 701-706. [CrossRef] [PubMed]

72. Anholt, R.R.; Aebi, U.; Pedersen, P.L.; Snyder, S.H. Solubilization and reassembly of the mitochondrial benzodiazepine receptor. Biochemistry 1986, 25, 2120-2125. [CrossRef] [PubMed]

73. Lavisse, S.; Guillermier, M.; Hérard, A.-S.; Petit, F.; Delahaye, M.; van Camp, N.; Ben Haim, L.; Lebon, V.; Remy, P.; Dollé, F.; et al. Reactive astrocytes overexpress TSPO and are detected by TSPO positron emission tomography imaging. J. Neurosci. 2012, 32, 10809-10818. [CrossRef] [PubMed]

74. Rizzo, G.; Veronese, M.; Tonietto, M.; Zanotti-Fregonara, P.; Turkheimer, F.E.; Bertoldo, A. Kinetic modeling without accounting for the vascular component impairs the quantification of [(11)C]PBR28 brain PET data. J. Cereb. Blood Flow Metab. 2014, 34, 1060-1069. [CrossRef] [PubMed]

75. Hannestad, J.; DellaGioia, N.; Gallezot, J.-D.; Lim, K.; Nabulsi, N.; Esterlis, I.; Pittman, B.; Lee, J.-Y.; O'Connor, K.C.; Pelletier, D.; et al. The neuroinflammation marker translocator protein is not elevated in individuals with mild-to-moderate depression: A [ ${ }^{11}$ C]PBR28 PET study. Brain Behav. Immun. 2013, 33, 131-138. [CrossRef] [PubMed] 
76. Dierckx, R.A.J.O.; Otte, A.; de Vries, E.F.J.; van Waarde, A.; Luiten, P.G.M. PET and SPECT of Neurobiological Systems; Springer: Berlin/Heidelberg, Germany, 2014.

77. dD Vries, E.F.J.; Doorduin, J.; Dierckx, R.A.; van Waarde, A. Evaluation of [(11)C]rofecoxib as PET tracer for cyclooxygenase 2 overexpression in rat models of inflammation. Nucl. Med. Biol. 2008, 35, 35-42. [CrossRef] [PubMed]

78. Shukuri, M.; Mawatari, A.; Ohno, M.; Suzuki, M.; Doi, H.; Watanabe, Y.; Onoe, H. Detection of cyclooxygenase-1 in activated microglia during amyloid plaque progression: PET studies in Alzheimer's disease model mice. J. Nucl. Med. 2016, 57, 291-296. [CrossRef] [PubMed]

79. Contartese, A.; Valoti, M.; Corelli, F.; Pasquini, S.; Mugnaini, C.; Pessina, F.; Aldinucci, C.; Sgaragli, G.; Frosini, M. A novel CB2 agonist, COR167, potently protects rat brain cortical slices against OGD and reperfusion injury. Pharmacol. Res. 2012, 66, 555-563. [CrossRef] [PubMed]

80. Slavik, R.; Grether, U.; Müller Herde, A.; Gobbi, L.; Fingerle, J.; Ullmer, C.; Krämer, S.D.; Schibli, R.; Mu, L.; Ametamey, S.M. Discovery of a high affinity and selective pyridine analog as a potential positron emission tomography imaging agent for cannabinoid type 2 receptor. J. Med. Chem. 2015, 58, 4266-4277. [CrossRef] [PubMed]

81. Janssen, B.; Vugts, D.J.; Funke, U.; Spaans, A.; Schuit, R.C.; Kooijman, E.; Rongen, M.; Perk, L.R.; Lammertsma, A.A.; Windhorst, A.D. Synthesis and initial preclinical evaluation of the P2X7 receptor antagonist $\left[{ }^{11} \mathrm{C}\right] \mathrm{A}-740003$ as a novel tracer of neuroinflammation. J. Label. Comp. Radiopharm. 2014, 57, 509-516. [CrossRef] [PubMed]

82. Territo, P.R.; Meyer, J.A.; Peters, J.S.; Riley, A.A.; McCarthy, B.P.; Gao, M.; Wang, M.; Green, M.A.; Zheng, Q.-H.; Hutchins, G.D. Characterization of [11C]-GSK1482160 for targeting the P2X7 receptor as a biomarker for neuroinflammation. J. Nucl. Med. 2016, 58, 458-465. [CrossRef] [PubMed]

83. Antunes, I.F.; Doorduin, J.; Haisma, H.J.; Elsinga, P.H.; van Waarde, A.; Willemsen, A.T.M.; Dierckx, R.A.; de Vries, E.F.J. 18F-FEAnGA for PET of $\beta$-glucuronidase activity in neuroinflammation. J. Nucl. Med. 2012, 53, 451-458. [CrossRef] [PubMed]

84. Mishina, M.; Ishiwata, K.; Naganawa, M.; Kimura, Y.; Kitamura, S.; Suzuki, M.; Hashimoto, M.; Ishibashi, K.; Oda, K.; Sakata, M.; et al. Adenosine A(2A) receptors measured with [C]TMSX PET in the striata of Parkinson's disease patients. PLoS ONE 2011, 6, e17338. [CrossRef] [PubMed]

85. Rissanen, E.; Virta, J.R.; Paavilainen, T.; Tuisku, J.; Helin, S.; Luoto, P.; Parkkola, R.; Rinne, J.O.; Airas, L. Adenosine A2A receptors in secondary progressive multiple sclerosis: A [(11)C]TMSX brain PET study. J. Cereb. Blood Flow Metab. 2013, 33, 1394-1401. [CrossRef] [PubMed]

86. Martín, A.; Szczupak, B.; Gómez-Vallejo, V.; Domercq, M.; Cano, A.; Padro, D.; Muñoz, C.; Higuchi, M.; Matute, C.; Llop, J. In vivo PET imaging of the $\alpha 4 \beta 2$ nicotinic acetylcholine receptor as a marker for brain inflammation after cerebral ischemia. J. Neurosci. 2015, 35, 5998-6009. [CrossRef] [PubMed]

87. Liu, Q.; Pan, D.; Cheng, C.; Zhang, D.; Zhang, A.; Wang, L.; Jiang, H.; Wang, T.; Liu, H.; Xu, Y.; et al. Development of a novel PET tracer [18F]AlF-NOTA-C6 targeting MMP2 for tumor imaging. PLoS ONE 2015, 10, e0141668. [CrossRef] [PubMed]

88. Zinnhardt, B.; Viel, T.; Wachsmuth, L.; Vrachimis, A.; Wagner, S.; Breyholz, H.-J.; Faust, A.; Hermann, S.; Kopka, K.; Faber, C.; et al. Multimodal imaging reveals temporal and spatial microglia and matrix metalloproteinase activity after experimental stroke. J. Cereb. Blood Flow Metab. 2015, 35, 1711-1721. [CrossRef] [PubMed]

89. Smith, A.C.W.; Scofield, M.D.; Kalivas, P.W. The tetrapartite synapse: Extracellular matrix remodeling contributes to corticoaccumbens plasticity underlying drug addiction. Brain Res. 2015, 1628, 29-39. [CrossRef] [PubMed]

90. Cartier, L.; Hartley, O.; Dubois-Dauphin, M.; Krause, K.-H. Chemokine receptors in the central nervous system: Role in brain inflammation and neurodegenerative diseases. Brain Res. Brain Res. Rev. 2005, 48, 16-42. [CrossRef] [PubMed]

91. Glass, C.K.; Saijo, K.; Winner, B.; Marchetto, M.C.; Gage, F.H. Mechanisms underlying inflammation in neurodegeneration. Cell 2010, 140, 918-934. [CrossRef] [PubMed]

92. Phillis, J.W.; Horrocks, L.A.; Farooqui, A.A. Cyclooxygenases, lipoxygenases, and epoxygenases in CNS: Their role and involvement in neurological disorders. Brain Res. Rev. 2006, 52, 201-243. [CrossRef] [PubMed]

93. Smith, W.L.; Garavito, R.M.; DeWitt, D.L. Prostaglandin endoperoxide H synthases (cyclooxygenases)-1 and -2. J. Biol. Chem. 1996, 271, 33157-33160. [CrossRef] [PubMed] 
94. Breder, C.D.; Dewitt, D.; Kraig, R.P. Characterization of inducible cyclooxygenase in rat brain. J. Comp. Neurol. 1995, 355, 296-315. [CrossRef] [PubMed]

95. Andreasson, K.I.; Savonenko, A.; Vidensky, S.; Goellner, J.J.; Zhang, Y.; Shaffer, A.; Kaufmann, W.E.; Worley, P.F.; Isakson, P.; Markowska, A.L. Age-dependent cognitive deficits and neuronal apoptosis in cyclooxygenase-2 transgenic mice. J. Neurosci. 2001, 21, 8198-8209. [PubMed]

96. Yamagata, K.; Andreasson, K.I.; Kaufmann, W.E.; Barnes, C.A.; Worley, P.F. Expression of a mitogen-inducible cyclooxygenase in brain neurons: Regulation by synaptic activity and glucocorticoids. Neuron 1993, 11, 371-386. [CrossRef]

97. Katori, M.; Majima, M. Cyclooxygenase-2: Its rich diversity of roles and possible application of its selective inhibitors. Inflamm. Res. 2000, 49, 367-392. [CrossRef] [PubMed]

98. Minghetti, L. Cyclooxygenase-2 (COX-2) in inflammatory and degenerative brain diseases. J. Neuropathol. Exp. Neurol. 2004, 63, 901-910. [CrossRef] [PubMed]

99. Majo, V.J.; Prabhakaran, J.; Simpson, N.R.; van Heertum, R.L.; Mann, J.J.; Kumar, J.S.D. A general method for the synthesis of aryl [11C]methylsulfones: Potential PET probes for imaging cyclooxygenase-2 expression. Bioorg. Med. Chem. Lett. 2005, 15, 4268-4271. [CrossRef] [PubMed]

100. De Vries, E.F.J.; Dierckx, R.A.; Klein, H.C. Nuclear imaging of inflammation in neurologic and psychiatric disorders. Curr. Clin. Pharmacol. 2006, 1, 229-242. [CrossRef] [PubMed]

101. Laube, M.; Kniess, T.; Pietzsch, J. Radiolabeled COX-2 inhibitors for non-invasive visualization of COX-2 expression and activity: A critical update. Molecules 2013, 18, 6311-6355. [CrossRef] [PubMed]

102. Shukuri, M.; Takashima-Hirano, M.; Tokuda, K.; Takashima, T.; Matsumura, K.; Inoue, O.; Doi, H.; Suzuki, M.; Watanabe, Y.; Onoe, H. In vivo expression of cyclooxygenase-1 in activated microglia and macrophages during neuroinflammation visualized by PET with 11C-ketoprofen methyl ester. J. Nucl. Med. 2011, 52, 1094-1101. [CrossRef] [PubMed]

103. Panagis, G.; Mackey, B.; Vlachou, S. Cannabinoid regulation of brain reward processing with an emphasis on the role of CB1 receptors: A step back into the future. Front. Psychiatry 2014, 5, 92. [CrossRef] [PubMed]

104. Van Sickle, M.D.; Duncan, M.; Kingsley, P.J.; Mouihate, A.; Urbani, P.; Mackie, K.; Stella, N.; Makriyannis, A.; Piomelli, D.; Davison, J.S.; et al. Identification and functional characterization of brainstem cannabinoid CB2 receptors. Science 2005, 310, 329-332. [CrossRef] [PubMed]

105. Onaivi, E.S. Cannabinoid receptors in brain: Pharmacogenetics, neuropharmacology, neurotoxicology, and potential therapeutic applications. Int. Rev. Neurobiol. 2009, 88, 335-369. [PubMed]

106. Sheng, W.S.; Hu, S.; Min, X.; Cabral, G.A.; Lokensgard, J.R.; Peterson, P.K. Synthetic cannabinoid WIN55,212-2 inhibits generation of inflammatory mediators by IL-1beta-stimulated human astrocytes. Glia 2005, 49, 211-219. [CrossRef] [PubMed]

107. Golech, S.A.; McCarron, R.M.; Chen, Y.; Bembry, J.; Lenz, F.; Mechoulam, R.; Shohami, E.; Spatz, M. Human brain endothelium: Coexpression and function of vanilloid and endocannabinoid receptors. Brain Res. Mol. Brain Res. 2004, 132, 87-92. [CrossRef] [PubMed]

108. Benito, C.; Tolón, R.M.; Pazos, M.R.; Núñez, E.; Castillo, A.I.; Romero, J. Cannabinoid CB2 receptors in human brain inflammation. Br. J. Pharmacol. 2008, 153, 277-285. [CrossRef] [PubMed]

109. Sagredo, O.; González, S.; Aroyo, I.; Pazos, M.R.; Benito, C.; Lastres-Becker, I.; Romero, J.P.; Tolón, R.M.; Mechoulam, R.; Brouillet, E.; et al. Cannabinoid CB2 receptor agonists protect the striatum against malonate toxicity: Relevance for Huntington's disease. Glia 2009, 57, 1154-1167. [CrossRef] [PubMed]

110. Palazuelos, J.; Aguado, T.; Pazos, M.R.; Julien, B.; Carrasco, C.; Resel, E.; Sagredo, O.; Benito, C.; Romero, J.; Azcoitia, I.; et al. Microglial CB2 cannabinoid receptors are neuroprotective in Huntington's disease excitotoxicity. Brain 2009, 132, 3152-3164. [CrossRef] [PubMed]

111. Eljaschewitsch, E.; Witting, A.; Mawrin, C.; Lee, T.; Schmidt, P.M.; Wolf, S.; Hoertnagl, H.; Raine, C.S.; Schneider-Stock, R.; Nitsch, R.; et al. The endocannabinoid anandamide protects neurons during CNS inflammation by induction of MKP-1 in microglial cells. Neuron 2006, 49, 67-79. [CrossRef] [PubMed]

112. Jia, J.; Peng, J.; Li, Z.; Wu, Y.; Wu, Q.; Tu, W.; Wu, M. Cannabinoid CB2 Receptor mediates nicotine-induced anti-inflammation in N9 microglial cells exposed to $\beta$ amyloid via protein kinase C. Mediat. Inflamm. 2016, 2016, 4854378. [CrossRef] [PubMed]

113. Evens, N.; Vandeputte, C.; Coolen, C.; Janssen, P.; Sciot, R.; Baekelandt, V.; Verbruggen, A.M.; Debyser, Z.; van Laere, K.; Bormans, G.M. Preclinical evaluation of [11C]NE40, a type 2 cannabinoid receptor PET tracer. Nucl. Med. Biol. 2012, 39, 389-399. [CrossRef] [PubMed] 
114. Ahmad, R.; Koole, M.; Evens, N.; Serdons, K.; Verbruggen, A.; Bormans, G.; Van Laere, K. Whole-body biodistribution and radiation dosimetry of the cannabinoid type 2 receptor ligand [11C]-NE40 in healthy subjects. Mol. Imaging Biol. 2013, 15, 384-390. [CrossRef] [PubMed]

115. Hortala, L.; Arnaud, J.; Roux, P.; Oustric, D.; Boulu, L.; Oury-Donat, F.; Avenet, P.; Rooney, T.; Alagille, D.; Barret, O.; et al. Synthesis and preliminary evaluation of a new fluorine-18 labelled triazine derivative for PET imaging of cannabinoid CB2 receptor. Bioorg. Med. Chem. Lett. 2014, 24, 283-287. [CrossRef] [PubMed]

116. Slavik, R.; Müller Herde, A.; Haider, A.; Krämer, S.D.; Weber, M.; Schibli, R.; Ametamey, S.M.; Mu, L. Discovery of a fluorinated 4-oxo-quinoline derivative as a potential positron emission tomography radiotracer for imaging cannabinoid receptor type 2. J. Neurochem. 2016, 138, 874-886. [CrossRef] [PubMed]

117. Ahamed, M.; van Veghel, D.; Ullmer, C.; van Laere, K.; Verbruggen, A.; Bormans, G.M. Synthesis, biodistribution and in vitro evaluation of brain permeable high affinity type 2 cannabinoid receptor agonists [(11)C]MA2 and [(18)F]MA3. Front. Neurosci. 2016, 10, 431. [CrossRef] [PubMed]

118. Collo, G.; Neidhart, S.; Kawashima, E.; Kosco-Vilbois, M.; North, R.A.; Buell, G. Tissue distribution of the P2X7 receptor. Neuropharmacology 1997, 36, 1277-1283. [CrossRef]

119. Sim, J.A.; Young, M.T.; Sung, H.-Y.; North, R.A.; Surprenant, A. Reanalysis of P2X7 Receptor Expression in Rodent Brain. J. Neurosci. 2004, 24, 6307-6314. [CrossRef] [PubMed]

120. Chakfe, Y.; Seguin, R.; Antel, J.P.; Morissette, C.; Malo, D.; Henderson, D.; Séguéla, P. ADP and AMP induce interleukin-1beta release from microglial cells through activation of ATP-primed P2X7 receptor channels. J. Neurosci. 2002, 22, 3061-3069. [PubMed]

121. Duan, S.; Anderson, C.M.; Keung, E.C.; Chen, Y.; Chen, Y.; Swanson, R.A. P2X7 receptor-mediated release of excitatory amino acids from astrocytes. J. Neurosci. 2003, 23, 1320-1328. [PubMed]

122. Parvathenani, L.K.; Tertyshnikova, S.; Greco, C.R.; Roberts, S.B.; Robertson, B.; Posmantur, R. P2X7 mediates superoxide production in primary microglia and is up-regulated in a transgenic mouse model of Alzheimer's disease. J. Biol. Chem. 2003, 278, 13309-13317. [CrossRef] [PubMed]

123. Yiangou, Y.; Facer, P.; Durrenberger, P.; Chessell, I.P.; Naylor, A.; Bountra, C.; Banati, R.R.; Anand, P. COX-2, CB2 and P2X7-immunoreactivities are increased in activated microglial cells/macrophages of multiple sclerosis and amyotrophic lateral sclerosis spinal cord. BMC Neurol. 2006, 6, 12. [CrossRef] [PubMed]

124. Díaz-Hernández, M.; Díez-Zaera, M.; Sánchez-Nogueiro, J.; Gómez-Villafuertes, R.; Canals, J.M.; Alberch, J.; Miras-Portugal, M.T.; Lucas, J.J. Altered P2X7-receptor level and function in mouse models of Huntington's disease and therapeutic efficacy of antagonist administration. FASEB J. 2009, 23, 1893-1906. [CrossRef] [PubMed]

125. Apolloni, S.; Amadio, S.; Parisi, C.; Matteucci, A.; Potenza, R.L.; Armida, M.; Popoli, P.; D'Ambrosi, N.; Volonté, C. Spinal cord pathology is ameliorated by P2X7 antagonism in a SOD1-mutant mouse model of amyotrophic lateral sclerosis. Dis. Model. Mech. 2014, 7, 1101-1109. [CrossRef] [PubMed]

126. Higashi, Y.; Aratake, T.; Shimizu, S.; Shimizu, T.; Nakamura, K.; Tsuda, M.; Yawata, T.; Ueba, T.; Saito, M. Influence of extracellular zinc on M1 microglial activation. Sci. Rep. 2017, 7, 43778. [CrossRef] [PubMed]

127. de Torre-Minguela, C.; Barberà-Cremades, M.; Gómez, A.I.; Martín-Sánchez, F.; Pelegrín, P. Macrophage activation and polarization modify P2X7 receptor secretome influencing the inflammatory process. Sci. Rep. 2016, 6, 22586. [CrossRef] [PubMed]

128. Ory, D.; Celen, S.; Gijsbers, R.; van den Haute, C.; Postnov, A.; Koole, M.; Vandeputte, C.; Andrés, J.-I.; Alcazar, J.; de Angelis, M.; et al. Preclinical evaluation of a P2X7 receptor-selective radiotracer: PET studies in a rat model with local overexpression of the human P2X7 receptor and in nonhuman primates. J. Nucl. Med. 2016, 57, 1436-1441. [CrossRef] [PubMed]

129. Ali, Z.; Laurijssens, B.; Ostenfeld, T.; McHugh, S.; Stylianou, A.; Scott-Stevens, P.; Hosking, L.; Dewit, O.; Richardson, J.C.; Chen, C. Pharmacokinetic and pharmacodynamic profiling of a P2X7 receptor allosteric modulator GSK1482160 in healthy human subjects. Br. J. Clin. Pharmacol. 2013, 75, 197-207. [CrossRef] [PubMed]

130. Shimoi, K.; Saka, N.; Nozawa, R.; Sato, M.; Amano, I.; Nakayama, T.; Kinae, N. Deglucuronidation of a flavonoid, luteolin monoglucuronide, during inflammation. Drug Metab. Dispos. 2001, 29, 1521-1524. [PubMed]

131. Shimoi, K.; Nakayama, T. Glucuronidase deconjugation in inflammation. Meth. Enzymol. 2005, 400, $263-272$. [PubMed] 
132. Cross, A.J.; Crow, T.J.; Dawson, J.M.; Ferrier, I.N.; Johnson, J.A.; Peters, T.J.; Reynolds, G.P. Subcellular pathology of human neurodegenerative disorders: Alzheimer-type dementia and Huntington's disease. J. Neurochem. 1986, 47, 882-889. [CrossRef] [PubMed]

133. Chen, J.-F.; Sonsalla, P.K.; Pedata, F.; Melani, A.; Domenici, M.R.; Popoli, P.; Geiger, J.; Lopes, L.V.; de Mendonça, A. Adenosine A2A receptors and brain injury: Broad spectrum of neuroprotection, multifaceted actions and "fine tuning" modulation. Prog. Neurobiol. 2007, 83, 310-331. [CrossRef] [PubMed]

134. Rebola, N.; Simões, A.P.; Canas, P.M.; Tomé, A.R.; Andrade, G.M.; Barry, C.E.; Agostinho, P.M.; Lynch, M.A.; Cunha, R.A. Adenosine A2A receptors control neuroinflammation and consequent hippocampal neuronal dysfunction. J. Neurochem. 2011, 117, 100-111. [CrossRef] [PubMed]

135. Orr, A.G.; Orr, A.L.; Li, X.-J.; Gross, R.E.; Traynelis, S.F. Adenosine A(2A) receptor mediates microglial process retraction. Nat. Neurosci. 2009, 12, 872-878. [CrossRef] [PubMed]

136. Zhou, X.; Boellaard, R.; Ishiwata, K.; Sakata, M.; Dierckx, R.A.; de Jong, J.; Nishiyama, S.; Ohba, H.; Tsukada, H.; de Vries, E.F.; et al. In vivo evaluation of [11C]preladenant for PET-imaging of adenosine A2A receptors in the conscious monkey. J. Nucl. Med. 2017. [CrossRef] [PubMed]

137. Khanapur, S.; van Waarde, A.; Dierckx, R.A.; Elsinga, P.H.; Koole, M. Preclinical evaluation and quantification of 18F-Fluoroethyl and 18F-Fluoropropyl analogs of SCH442416 as radioligands for PET imaging of the adenosine A2A receptors in rat brain. J. Nucl. Med. 2016. [CrossRef]

138. Matos, M.; Shen, H.-Y.; Augusto, E.; Wang, Y.; Wei, C.J.; Wang, Y.T.; Agostinho, P.; Boison, D.; Cunha, R.A.; Chen, J.-F. Deletion of adenosine A2A receptors from astrocytes disrupts glutamate homeostasis leading to psychomotor and cognitive impairment: Relevance to schizophrenia. Biol. Psychiatry 2015, 78, 763-774. [CrossRef] [PubMed]

139. Chen, J.-F.; Lee, C.; Chern, Y. Adenosine receptor neurobiology: Overview. Int. Rev. Neurobiol. 2014, 119, 1-49. [PubMed]

140. Bottlaender, M.; Valette, H.; Roumenov, D.; Dollé, F.; Coulon, C.; Ottaviani, M.; Hinnen, F.; Ricard, M. Biodistribution and radiation dosimetry of 18F-fluoro-A-85380 in healthy volunteers. J. Nucl. Med. 2003, 44, 596-601. [PubMed]

141. Schmaljohann, J.; Minnerop, M.; Karwath, P.; Gündisch, D.; Falkai, P.; Guhlke, S.; Wüllner, U. Imaging of central nAChReceptors with 2-[18F]F-A85380: Optimized synthesis and in vitro evaluation in Alzheimer's disease. Appl. Radiat. Isot. 2004, 61, 1235-1240. [CrossRef] [PubMed]

142. Choi, D.-H.; Kim, Y.-J.; Kim, Y.-G.; Joh, T.H.; Beal, M.F.; Kim, Y.-S. Role of matrix metalloproteinase 3-mediated alpha-synuclein cleavage in dopaminergic cell death. J. Biol. Chem. 2011, 286, 14168-14177. [CrossRef] [PubMed]

143. Shin, E.J.; Kim, E.-M.; Lee, J.A.; Rhim, H.; Hwang, O. Matrix metalloproteinase-3 is activated by HtrA2/Omi in dopaminergic cells: Relevance to Parkinson's disease. Neurochem. Int. 2012, 60, 249-256. [CrossRef] [PubMed]

144. Wagner, S.; Faust, A.; Breyholz, H.-J.; Schober, O.; Schäfers, M.; Kopka, K. The MMP inhibitor (R)-2-(N-benzyl-4-(2-[18F]fluoroethoxy)phenylsulphonamido)-N-hydroxy-3-methylbutanamide: Improved precursor synthesis and fully automated radiosynthesis. Appl. Radiat. Isot. 2011, 69, 862-868. [CrossRef] [PubMed]

145. Zinnhardt, B.; Pigeon, H.; Thézé, B.; Viel, T.; Wachsmuth, L.; Fricke, I.B.; Schelhaas, S.; Honold, L.; Schwegmann, K.; Wagner, S.; et al. Combined PET imaging of the inflammatory tumor microenvironment identifies margins of unique radiotracer uptake. Cancer Res. 2017. [CrossRef] [PubMed]

146. Hugenberg, V.; Breyholz, H.-J.; Riemann, B.; Hermann, S.; Schober, O.; Schäfers, M.; Gangadharmath, U.; Mocharla, V.; Kolb, H.; Walsh, J.; et al. A new class of highly potent matrix metalloproteinase inhibitors based on triazole-substituted hydroxamates: (Radio)synthesis and in vitro and first in vivo evaluation. J. Med. Chem. 2012, 55, 4714-4727. [CrossRef] [PubMed]

147. Hugenberg, V.; Wagner, S.; Kopka, K.; Schäfers, M.; Schuit, R.C.; Windhorst, A.D.; Hermann, S. Radiolabeled selective matrix metalloproteinase 13 (MMP-13) inhibitors: (Radio)Syntheses and in vitro and first in vivo evaluation. J. Med. Chem. 2017, 60, 307-321. [CrossRef] [PubMed]

148. Franco, R.; Fernández-Suárez, D. Alternatively activated microglia and macrophages in the central nervous system. Prog. Neurobiol. 2015, 131, 65-86. [CrossRef] [PubMed] 
149. Huang, H.J.; Isakow, W.; Byers, D.E.; Engle, J.T.; Griffin, E.A.; Kemp, D.; Brody, S.L.; Gropler, R.J.; Miller, J.P.; $\mathrm{Chu}, \mathrm{W}$; , et al. Imaging pulmonary inducible nitric oxide synthase expression with PET. J. Nucl. Med. 2015, 56, 76-81. [CrossRef] [PubMed]

150. Kularatne, S.A.; Bélanger, M.-J.; Meng, X.; Connolly, B.M.; Vanko, A.; Suresch, D.L.; Guenther, I.; Wang, S.; Low, P.S.; McQuade, P.; et al. Comparative analysis of folate derived PET imaging agents with [(18)F]-2-fluoro-2-deoxy-d-glucose using a rodent inflammatory paw model. Mol. Pharm. 2013, 10, 3103-3111. [CrossRef] [PubMed]

151. Gent, Y.Y.J.; Weijers, K.; Molthoff, C.F.M.; Windhorst, A.D.; Huisman, M.C.; Smith, D.E.C.; Kularatne, S.A.; Jansen, G.; Low, P.S.; Lammertsma, A.A.; et al. Evaluation of the novel folate receptor ligand [18F]fluoro-PEG-folate for macrophage targeting in a rat model of arthritis. Arthritis Res. Ther. 2013, 15, R37. [CrossRef] [PubMed]

152. Huang, X.; Gillies, R.J.; Tian, H. Synthesis of [(18) F] 4-amino-N-(3-chloro-4-fluorophenyl)-N'-hydroxy-1,2,5oxadiazole-3-carboximidamide (IDO5L): A novel potential PET probe for imaging of IDO1 expression. J. Label. Comp. Radiopharm. 2015, 58, 156-162. [CrossRef] [PubMed]

153. Parrott, J.M.; O'Connor, J.C. Kynurenine 3-Monooxygenase: An influential mediator of neuropathology. Front Psychiatry 2015, 6, 116. [CrossRef] [PubMed]

154. Gachet, C. P2Y12 receptors in platelets and other hematopoietic and non-hematopoietic cells. Purinergic Signal 2012, 8, 609-619. [CrossRef] [PubMed]

155. Moore, C.S.; Ase, A.R.; Kinsara, A.; Rao, V.T.S.; Michell-Robinson, M.; Leong, S.Y.; Butovsky, O.; Ludwin, S.K.; Séguéla, P.; Bar-Or, A.; et al. P2Y12 expression and function in alternatively activated human microglia. Neurol. Neuroimmunol. Neuroinflamm. 2015, 2, e80. [CrossRef] [PubMed]

156. Kerwin, J.F.; Heller, M. The arginine-nitric oxide pathway: A target for new drugs. Med. Res. Rev. 1994, 14, 23-74. [CrossRef] [PubMed]

157. Brown, G.C. Mechanisms of inflammatory neurodegeneration: iNOS and NADPH oxidase. Biochem. Soc. Trans. 2007, 35, 1119-1121. [CrossRef] [PubMed]

158. Murphy, S. Production of nitric oxide by glial cells: Regulation and potential roles in the CNS. Glia 2000, 29, 1-13. [CrossRef]

159. Zhou, D.; Huang, C.; Lin, Z.; Zhan, S.; Kong, L.; Fang, C.; Li, J. Macrophage polarization and function with emphasis on the evolving roles of coordinated regulation of cellular signaling pathways. Cell Signal. 2014, 26, 192-197. [CrossRef] [PubMed]

160. Zhou, D.; Lee, H.; Rothfuss, J.M.; Chen, D.L.; Ponde, D.E.; Welch, M.J.; Mach, R.H. Design and synthesis of 2-Amino-4-methylpyridine analogues as inhibitors for inducible nitric oxide synthase and in vivo evaluation of [ ${ }^{18} \mathrm{~F}$ 6-(2-Fluoropropyl)-4-methyl-pyridin-2-amine as a potential PET tracer for inducible nitric oxide synthase. J. Med. Chem. 2009, 52, 2443-2453. [CrossRef] [PubMed]

161. Low, P.S.; Antony, A.C. Folate receptor-targeted drugs for cancer and inflammatory diseases. Adv. Drug Deliv. Rev. 2004, 56, 1055-1058. [CrossRef] [PubMed]

162. Matthews, P.M.; Datta, G. Positron-emission tomography molecular imaging of glia and myelin in drug discovery for multiple sclerosis. Expert Opin. Drug Discov. 2015, 10, 557-570. [CrossRef] [PubMed]

163. Puig-Kröger, A.; Sierra-Filardi, E.; Domínguez-Soto, A.; Samaniego, R.; Corcuera, M.T.; Gómez-Aguado, F.; Ratnam, M.; Sánchez-Mateos, P.; Corbí, A.L. Folate receptor beta is expressed by tumor-associated macrophages and constitutes a marker for M2 anti-inflammatory/regulatory macrophages. Cancer Res. 2009, 69, 9395-9403. [CrossRef] [PubMed]

164. MacDowell, K.S.; Caso, J.R.; Martín-Hernández, D.; Moreno, B.M.; Madrigal, J.L.M.; Micó, J.A.; Leza, J.C.; García-Bueno, B. The atypical antipsychotic paliperidone regulates endogenous antioxidant/ anti-inflammatory pathways in rat models of acute and chronic restraint stress. Neurotherapeutics 2016, 13, 833-843. [CrossRef] [PubMed]

165. Xia, W.; Hilgenbrink, A.R.; Matteson, E.L.; Lockwood, M.B.; Cheng, J.-X.; Low, P.S. A functional folate receptor is induced during macrophage activation and can be used to target drugs to activated macrophages. Blood 2009, 113, 438-446. [CrossRef] [PubMed]

166. Matteson, E.L.; Lowe, V.J.; Prendergast, F.G.; Crowson, C.S.; Moder, K.G.; Morgenstern, D.E.; Messmann, R.A.; Low, P.S. Assessment of disease activity in rheumatoid arthritis using a novel folate targeted radiopharmaceutical Folatescan ${ }^{\mathrm{TM}}$. Clin. Exp. Rheumatol. 2009, 27, 253-259. [PubMed] 
167. Lovelace, M.D.; Varney, B.; Sundaram, G.; Lennon, M.J.; Lim, C.K.; Jacobs, K.; Guillemin, G.J.; Brew, B.J. Recent evidence for an expanded role of the kynurenine pathway of tryptophan metabolism in neurological diseases. Neuropharmacology 2017, 112, 373-388. [CrossRef] [PubMed]

168. Wang, Y.; Lawson, M.A.; Kelley, K.W.; Dantzer, R. Primary murine microglia are resistant to nitric oxide inhibition of indoleamine 2,3-dioxygenase. Brain Behav. Immun. 2010, 24, 1249-1253. [CrossRef] [PubMed]

169. Mancuso, R.; Hernis, A.; Agostini, S.; Rovaris, M.; Caputo, D.; Fuchs, D.; Clerici, M. Indoleamine 2,3 dioxygenase (IDO) expression and activity in relapsing- remitting multiple sclerosis. PLoS ONE 2015, 10. [CrossRef] [PubMed]

170. Bonda, D.J.; Mailankot, M.; Stone, J.G.; Garrett, M.R.; Staniszewska, M.; Castellani, R.J.; Siedlak, S.L.; Zhu, X.; Lee, H.; Perry, G.; Nagaraj, R.H.; Smith, M.A. Indoleamine 2,3-dioxygenase and 3-hydroxykynurenine modifications are found in the neuropathology of Alzheimer's disease. Redox Rep. 2010, 15, 161-168. [CrossRef] [PubMed]

171. Widner, B.; Leblhuber, F.; Fuchs, D. Increased neopterin production and tryptophan degradation in advanced Parkinson's disease. J. Neural. Transm. 2002, 109, 181-189. [CrossRef] [PubMed]

172. Guillemin, G.J.; Brew, B.J.; Noonan, C.E.; Takikawa, O.; Cullen, K.M. Indoleamine 2,3 dioxygenase and quinolinic acid Immunoreactivity in Alzheimer's disease hippocampus. Neuropathol. Appl. Neurobiol. 2005, 31, 395-404. [CrossRef] [PubMed]

173. Guastella, A.R.; Michelhaugh, S.K.; Klinger, N.V.; Kupsky, W.J.; Polin, L.A.; Muzik, O.; Juhász, C.; Mittal, S. Tryptophan PET imaging of the kynurenine pathway in patient-derived xenograft models of glioblastoma. Mol. Imaging 2016. [CrossRef] [PubMed]

174. Mildner, A.; Huang, H.; Radke, J.; Stenzel, W.; Priller, J. P2Y12 receptor is expressed on human microglia under physiological conditions throughout development and is sensitive to neuroinflammatory diseases. Glia 2017, 65, 375-387. [CrossRef] [PubMed]

175. Amadio, S.; Parisi, C.; Montilli, C.; Carrubba, A.S.; Apolloni, S.; Volonté, C. P2Y(12) receptor on the verge of a neuroinflammatory breakdown. Mediators Inflamm. 2014, 2014, 975849. [CrossRef] [PubMed]

176. Pevarello, P.; Bovolenta, S.; Tarroni, P.; Za, L.; Severi, E.; Torino, D.; Vitalone, R. P2X7 antagonists for CNS indications: Recent patent disclosures. Pharm. Pat. Anal. 2017, 6, 61-76. [CrossRef] [PubMed]

(C) 2017 by the authors. Licensee MDPI, Basel, Switzerland. This article is an open access article distributed under the terms and conditions of the Creative Commons Attribution (CC BY) license (http:/ / creativecommons.org/licenses/by/4.0/). 